\title{
VYUŽITIE LOKALIZAČNÝCH DÁT MOBILNEJ SIETE V TURIZME: KTO SÚ, KEDY PRICCHÁDZAJÚ A KAM SMERUJÚ ZAHRANIČNİ NÁVŠTEVNÍCI NA SLOVENSKU?
}

\author{
Martin Šveda*, František Križan**, Peter Barlík*** \\ * Univerzita Komenského v Bratislave, Prírodovedecká fakulta, Katedra regionálnej geografie, ochrany \\ a plánovania krajiny, Mlynská dolina, Ilkovičova 6, 84215 Bratislava, Geografický ústav SAV, Štefánikova 49, \\ 81473 Bratislava, martin.sveda@uniba.sk \\ ** Univerzita Komenského v Bratislave, Prírodovedecká fakulta, Katedra regionálnej geografie, ochrany \\ a plánovania krajiny, Mlynská dolina, Ilkovičova 6,84215 Bratislava, frantisek.krizan@uniba.sk \\ *** Market Locator SK s.r.o., 29. augusta 36/A, 81109 Bratislava, \\ Univerzita Komenského v Bratislave, Prírodovedecká fakulta, Katedra regionálnej geografie, ochrany \\ a plánovania krajiny, Mlynská dolina, Ilkovičova 6,842 15 Bratislava, \\ peter.barlik@marketlocator.com
}

\begin{abstract}
Utilizing mobile positioning data in tourism: Who are the foreign visitors in Slovakia? When do they come and where they stay?

One of the ways of studying the movement and behaviour of tourists is related to the use of mobile phones. The paper introduces the applicability of mobile positioning, which refers to the large-scale location data of subscribers of mobile network operators that are processed and stored in operators' systems. For tourism studies we use the database of the locations of roaming (foreign phones) call activities in network cells. A depersonalized dataset was collected by the mobile positioning company Market Locator from the network of three major Slovak mobile operators. The key task was to find a suitable methodological approach to extract useful information for tourism studies. We have used a simple algorithm to extract "tourists" from a larger dataset of all phone activities of foreign mobile users in Slovakia. Extracting the group of tourist we have modelled the seasonal pattern of visitor flows to destinations. The results proved that mobile positioning data has a potential for applications in tourism studies, but there is still the question of extracting more precise information from the quantitative database with limited features.
\end{abstract}

Key words: mobile positioning, tourism, big data, Slovakia

\section{ÚVOD}

Poznanie časovo-priestorových aspektov návštevnosti regiónov (lokalít) je elementárnym vstupom do akejkol'vek analýzy v rámci problematiky turizmu. Medzi kl'účové ukazovatele hodnotenia sezónnych trendov návštevnosti patrí najmä počet prenocovaní, ktorý sa sleduje a vykazuje podl'a krajiny trvalého pobytu návštevníkov (domáci a zahraniční návštevníci). Mesačný výkaz o činnosti ubytovacieho zariadenia sa predkladá za ubytovacie zariadenia cestovného ruchu zapísané do registra ubytovacích zariadení Statistického úradu Slovenskej republiky. Táto databáza predstavuje východiskový údaj pre manažment služieb, ktorého ciel'om je nastavit' produkty turizmu vzhl'adom na národnostné a sezónne špecifiká regionálnej návštevnosti. Śtatistika ubytovania sa však použiva nielen v oblasti turizmu, ale aj v rámci regionálnej politiky a na monitorovanie dosahov politík Európskej únie.

Inštitucionálne údaje o prenocovaniach však nemusia korešpondovat's reálnou návštevnostou, ked’že neevidujú jednodenných návštevníkov, ktorí na Slovensku neprenocujú, ako aj návštevníkov, ktorí prenocujú bez toho, aby boli zachytení v oficiálnej štatistike. Dôvodov pre vznik ,šedej zóny“ v ubytovaní je viacero a súvisia najmä s alternatívnymi formami ubytovania, či snahou o vyhnutie sa pla- 
teniu miestnych poplatkov a daní za ubytovanie. Objem neregistrovaných prenocovaní môžeme len odhadovat', avšak podl'a správy Medzinárodného menového fondu (Medina a Schneider 2018) tvorí objem šedej ekonomiky v pomere k HDP na Slovensku približne $15 \%$.

Analýza návštevnosti a priestorovej mobility v národných a regionálnych analýzach turizmu patrila vždy k dôležitým úlohám geografického výskumu. Avšak naša schopnost' zachytit' časovú a priestorovú mobilitu v detailnom pohl'ade bola doposial' limitovaná dostupnost'ou a spol'ahlivost'ou údajov, ako aj schopnost'ou vierohodne ich interpretovat'. Navyše, prenocovanie návštevníkov nemusí nevyhnutne znamenat' aj aktívny pobyt $\mathrm{v}$ danom regióne (lokalite prenocovania), najmä v prostredí malej krajiny, akou je Slovensko, kde je väčšina turistických ciel'ov l'ahko dosiahnutel'ných z jednej lokality. Predovšetkým prístupy v rámci geografie času vytvorili bohatý konceptuálny a metodický aparát na sledovanie časovopriestorového pohybu jednotlivcov (Hägerstrand 1970, Lenntorp 1976 a Ira 2001). Takto zamerané štúdie však napriek detailnej mierke pracujúcej s individuálnymi respondentami nadobudli len ojedinele charakter rozsiahlych výskumov, nehovoriac o vysokej náročnosti na zber a spracovanie individuálnych záznamov.

Súčasné technologické možnosti mobilnej komunikácie prinášajú nové zdroje údajov o priestorovom správaní obyvatel'ov (Ahas a Mark 2005). Mobilný telefón sa stal neoddelitel'nou súčast'ou každodenného života, ako aj prirodzenou výbavou aktérov v rámci turizmu. Prostredníctvom mobilného telefónu získavame informácie o turistických lokalitách, používame ho pri navigácii v neznámom prostredí, či ako nástroj na rezerváciu ubytovania a bezhotovostnú platbu. Pri súčasnej penetrácii mobilných telefónov v populácii (v krajinách EÚ bolo v roku 2015 registrovaných 1213 predplatitel'ov mobilnej hlasovej alebo dátovej služby na 1000 obyvatel'ov - Eurostat 2017) tak dostávame unikátny nástroj na zachytenie reálnych priestorových vzorov správania domácich, ako aj zahraničných návštevníkov (Ahas a Mark 2005, Calabrese a Ratti 2006 a Ahas et al. 2007a).

Ciel'om príspevku je zhodnotit' časové a priestorové aspekty pohybu zahraničných návštevníkov na Slovensku s využitím lokalizačných údajov mobilných telefónov a hl'adat' odpovede na nasledujúce výskumné otázky:

- Umožňuje lokalizácia prostredníctvom mobilnej siete identifikovat' časové (sezónne) a priestorové (regionálne) vzory návštevnosti podl'a krajín pôvodu?

- Aký časovo-priestorový obraz poskytujú lokalizačné údaje mobilných zariadení o pohybe zahraničných návštevníkov na Slovensku?

- Nakol'ko získané údaje o návštevnosti korešpondujú s oficiálnymi údajmi o počte prenocovaní?

Príspevok má charakter pilotnej štúdie a tomu je prispôsobená aj obsahová štruktúra, ktorá v úvodnej časti predstavuje základné princípy lokalizácie prostredníctvom mobilnej siete. Príspevok vychádza z databázy, ktorej vznik je na Slovensku unikátny, no prináša aj značné praktické obmedzenia, ktoré vyplývajú z technických a právnych limitov narábania s lokalizačnými údajmi mobilných telefónov. $\mathrm{V}$ dôsledku toho je metodický rozmer príspevku zúžený na relatívne jednoduchú analýzu a predstavuje tak len úzky výsek z bohatých možností spracovania týchto objemných dát. 


\section{LOKALIZÁCIA PROSTREDNÍCTVOM MOBILNEJ SIETE}

Mobilná lokalizácia predstavuje záznam polohy mobilného zariadenia prostredníctvom mobilnej siete. Vzhl'adom na technologické možnosti mobilnej siete existuje viacero techník, ktoré umožňujú identifikovat' polohu užívatela mobilného zariadenia. Najčastejšie ide o lokalizáciu na základe polohy základňovej stanice (Base Transceiver Station - BTS), ale využit' sa dá aj triangulácia vzdialenosti od viacerých staníc, či presné merania satelitného systému GPS (Šveda et al. 2017).

Samotné lokalizačné údaje môžeme principiálne rozdelit' na pasívne a aktívne (Ahas et al. 2007a). Kým pri pasívnom type ide o využitie existujúcich záznamov v rámci systému mobilného operátora, pri aktívnom type sa záznam vytvára na základe konkrétneho dopytu a s využitím špecializovaného softvéru. Osobitne môžeme uviest' ešte záznamy, ktoré sa zhromažd'ujú za jednotlivé technické komponenty mobilnej siete - štatistiku antén (Novák 2010).

Štatistika antén: Prevádzka mobilnej siete si vyžaduje sledovanie vytaženosti jednotlivých prenosových staníc mobilnej siete. $\mathrm{K}$ zaznamenanému počtu a dížke hovorov (či iných dátových prenosov) tak vieme priradit' priestorový atribút - polohu danej BTS. To však v praxi nemusí byt' jednoduché, ked’že rozmiestnenie prenosových staníc môže byt' súčastou neverejných strategických informácií mobilného operátora. V takom prípade je možné bodový charakter údajov transformovat' do fiktívnych polygónov prenosovej siete (napr. Thiessenove polygóny), alebo môžeme pristúpit' k agregácii údajov do iných priestorových jednotiek (napr. administratívneho členenia). Možnosti využitia štatistiky antén sú napríklad vo výskume dennej dynamiky mesta, ako perspektívne sa javí aj prepojenie týchto lokalizačných dát $\mathrm{s}$ údajmi zo sčítania obyvatel'stva (charakter zástavby a sociálno-demografické charakteristiky), či s databázou funkčného využitia zeme (Novák 2010).

Pasivna lokalizácia: Obdobne ako v prípade štatistiky antén ide o informácie, ktoré v realite už existujú. Informácie o činnosti telefónu (CDR - call detail records) slúžia ako podklad na vyúčtovanie hovorov, SMS a pod. Vzhladom na skutočnost', že k údajom o aktivite mobilného zariadenia vieme priradit' nielen polohu a časovú reláciu, ale aj niektoré základné informácie o užívatel'ovi (vek, pohlavie, fakturačná adresa a pod.), získavame relatívne detailnú databázu, ktorej využitie (pri zachovaní anonymity užívatel'ov, resp. pri agregovaní údajov) prináša nesmierne cenný zdroj (nielen) pre geografický výskum. Príkladom môže byt' využitie dennej a nočnej lokalizácie uživatel’ov, ktoré vytvárajú základnú kostru ich každodenných aktivít (domov - práca). Pohyb mobilného zariadenia medzi jednotlivými bunkami siete umožňuje skúmat' rýchlost' a intenzitu dopravy a v súčasnosti je už bežnou súčast'ou aplikácií poskytujúcich navigáciu. Pasívne lokalizačné údaje však poskytujú ovel'a väčšiu škálu využitia. Mobilný telefón dnes využívame nielen na komunikáciu, ale aj nakupovanie, zábavu či športové aktivity. Využitím niektorých doplnkových údajov, ktoré zaznamenávajú operátori vo svojich databázach, tak môžeme analyzovat' aj ovel'a špecifickejšie správanie l'udí, ako napr. využívanie MHD, parkovanie, tipovanie a pod.

Pasívne lokalizačné údaje mobilných telefónov (označované aj ako telco data, mobile positioning data, mobile phone tracking) predstavujú bezprecedentný nástroj poskytujúci stovky tisícov záznamov s vysokým priestorovým a časovým rozlíšením a s možnost'ou vytvárania dlhodobých a opakovaných zist'ovaní (Toole et al. 2015). Hoci sa ich potenciál javí ako značný a zber dát si nevyžaduje žiadne dodatočné technológie či softvér, ich praktické využitie prináša viacero otázok sú- 
visiacich najmä so schopnost'ou zabezpečit' ich korektné a bezpečné spracovanie (Novák et al. 2013). Na rozdiel od tradičného zberu údajov o populácii v podobe národných cenzov či dopravných štúdií, ktoré sú vytvárané s konkrétnymi zámermi pre správu spoločnosti či výskum, lokalizačné údaje mobilných zariadení vznikajú ako „vedl'ajš́ı” produkt prevádzky mobilnej siete (Arribas-Bel 2014). V dôsledku toho prináša práca s lokalizačnými údajmi mobilných telefónov viacero špecifík:

- Spracovanie vel'kého objemu dát (rádovo milióny záznamov) vytvára zvýšené požiadavky na hardvérové a softvérové spracovanie;

- Konštrukcia vhodných algoritmov na selekciu údajov a očistenie databázy od nežiaducich záznamov (napr. fiktívny pohyb užívatel’a vyvolaný striedavým pripojením k rôznym základňovým staniciam, tzv. hand-over noise);

- Presnost' lokalizácie závisí predovšetkým od architektúry mobilnej siete najmä od hustoty prenosových staníc, ich kapacity, smerovania a pod. V mestách sa presnost' lokalizácie pohybuje rádovo v stovkách metrov, vo vidieckych oblastiach rádovo v kilometroch;

- Nevyhnutnou podmienkou práce s lokalizačnými údajmi mobilných zariadení je práca s anonymizovanými údajmi, ktoré neumožňujú identifikovat' individuálneho užívatel'a (Ahas et al. 2008). Evidencia užívatel'ov pod fiktívnymi identifikátormi a lokalizačná presnost' na úrovni jednotlivých buniek mobilnej siete (rádovo stovky metrov) však neumožňujú presnú identifikáciu osôb.

Aktívna lokalizácia: Kým doteraz uvedené zdroje údajov vychádzajú z databázovej infraštruktúry prevádzkovatel'a mobilnej siete a ide o anonymizované (alebo agregované) dáta, pri aktívnej lokalizácii vznikajú záznamy o polohe individuálneho mobilného zariadenia na základe cieleného lokalizačného dopytu a s využitím špecializovaného softvéru. Nevyhnutnou podmienkou záznamu je informovaný súhlas uživatel'a mobilného zariadenia a presne stanovené podmienky charakteru a dížky záznamu. O právnych a etických zásadách spojených s aktívnou lokalizáciou diskutujú Ahas et al. (2007b), Dufková et al. (2008) či Novák (2010).

Od prvých pionierskych štúdií (Ratti et al. 2006 a Ahas et al. 2007a) využívajúcich údaje mobilnej lokalizácie pri priestorových analýzach uplynulo už desat'ročie. Za toto krátke obdobie však môžeme pozorovat’ rozmach výskumu založeného na spracovaní údajov mobilnej siete. Zvyšovanie početnosti a variabilita spôsobov využitia lokalizačných údajov mobilnej komunikácie sa realizuje súčasne s rozvojom mobilnej infraštruktúry smerom k vyššiemu pokrytiu a vyššej interoperabilite (Frattasi a Della Rosa 2017). Mobilná lokalizácia si tak získava stále väčšiu pozornost' nielen ako výskumná oblast', ale predovšetkým ako perspektívny obchodný produkt umožňujúci cielený marketing. Údaje mobilných sietí sa čoraz častejšie využívajú ako prostriedok na analýzu sociálneho prostredia (Lambiotte et al. 2008 a Blondel et al. 2010), v konštrukcii prediktívnych modelov l'udskej mobility (Song et al. 2010) a sú perspektívnym zdrojom údajov pre široké spektrum multidisciplinárnych aplikácií v sociálnych vedách, urbánnom plánovaní, v krízovom manažmente (Bengtsson et al. 2011) či v analýze šírenia epidémií (Wesolowski et al. 2012).

V bohatej palete využitia mobilnej lokalizácie (pozri Steenbruggen et al. 2015 pre rozsiahlejš́i prehl'ad literatúry) nachádzame aj turizmus, ktorého formy a aktéri podliehajú aktuálnym trendom smerujúcim $\mathrm{k}$ menšej organizovanosti a vyššej miere flexibility. Hoci v podmienkach slovenskej geografickej akademickej obce ide o pilotnú štúdiu, analýza turizmu na základe dát mobilnej lokalizácie je v zahranič- 
ných štúdiách využívaná čoraz častejšie (Ahas et al. 2008, Nilbe et al. 2014, Phithakkitnukoon et al. 2015, Li et al. 2018, Mamei a Colonna 2018 a Wang et al. 2018). Výhody využitia mobilnej lokalizácie v turizme v porovnaní s tradičnými oficiálnymi údajmi o ubytovaní možno zhrnút do štyroch bodov (Raun et al. 2016): 1) priestorová a časová presnost' údajov je lepšia; 2) časový rad údajov je dlhší; 3) analýza umožňuje evidovat' turistov počas návštevy konkrétnych lokalít a 4) zhromažd’ovanie a spracovanie digitálnych údajov je jednoduché a aktuálne. Turistická destinácia má pät’ základných dimenzií (Raun et al. 2016): časovú, priestorovú, kompozičnú, sociálnu a dynamickú. Všetky tieto dimenzie môžeme analyzovat' prostredníctvom mobilnej lokalizácie.

\section{DÁTA A METÓDY}

Lokalizačné údaje mobilných telefónov možno pri výskume analyzovat' mnohými prístupmi (Ahas et al. 2008, Raun 2016, Li et al. 2018 a Wang et al. 2018), pričom časový a priestorový (geografický) prístup zohráva kl'účovú úlohu. Dáta použité v tejto štúdii boli zozbierané $\mathrm{v}$ rámci telekomunikačnej siete troch najväčších operátorov na Slovensku a spracované spoločnost'ou Market Locator SK. Využitie služieb spracovatel'a umožňuje získat' agregované a anonymizované údaje a tým sa vyhnút' práci so zdrojovými individuálnymi údajmi, ktorých spracovanie v súčasných legislatívnych podmienkach by ani nebolo možné. Zaistenie bezpečného prístupu k dátam prostredníctvom spracovatel'skej spoločnosti tak prináša unikátnu možnost' ako využit' potenciál lokalizačných údajov mobilných telefónov pri maximálnom zabezpečení anonymity užívatel'ov. Na druhej strane, obmedzený prístup k neagregovaným dátam však do značnej miery limituje kontrolu nad spracovaním zdrojových údajov a tým aj prípadné zmeny parametrov filtračných algoritmov.

Lokalizácia mobilných zariadení v tejto štúdii je založená na údajoch, ktoré vznikajú pri aktivite mobilného zariadenia, tzv. call detail records (CDR). Tieto údaje obsahujú typ telekomunikačnej aktivity (prichádzajúci/odchádzajúci hovor, prichádzajúca/odchádzajúca SMS, pripojenie sa do mobilnej siete), čas a dátum aktivity, priestorovú informáciu (bunka mobilnej siete, v ktorej bola aktivita vykonaná) a samotný identifikátor SIM karty, ktorá vykonala aktivitu (anonymizované ID; krajina registrácie SIM karty). Výsledný dátový súbor obsahoval anonymizované údaje o 14365194 unikátnych zahraničných užívatel'och, ktorí sa pripojili do mobilne siete na Slovensku v roku 2016 prostredníctvom mobilných sietí Slovak Telekom, Orange Slovensko a O2 Slovensko. Celkovo bolo zaznamenaných 71705809 lokalizačných záznamov návštevníkov.

Predstavme si v jednoduchosti základné princípy evidencie zahraničných návštevníkov v rámci mobilnej siete na Slovensku. Pri príchode sa zahraničný návštevník po niekol'kých kilometroch po prekročení hranice dostáva mimo dosahu mobilnej siete krajiny, z ktorej prichádza, a vstupuje do polygónu pokrytia BTS jedného zo slovenských operátorov. Od tohto momentu (až do opustenia územia pokrytia slovenskými operátormi) sa užívatel' nachádza v spracovanej databáze, pričom záznam o svojej polohe poskytuje na základe pasívnej lokalizácie - teda priradením do jednej z buniek mobilnej siete.

Použitý dátový súbor zahŕňa všetkých zahraničných návštevníkov bez ohl'adu na dížku ich pobytu, či dôvod ich návštevy na území Slovenska. Preto kl'účovým metodickým krokom pri analýze turistickej návštevnosti bolo nájdenie takého algoritmu, ktorý by z databázy všetkých návštevníkov extrahoval záznamy najviac zod- 
povedajúce charakteristike turistov a súčasne by vylúčil tranzitných návštevníkov (napr. vodičov len prechádzajúcich cez Slovensko) či dlhodobých rezidentov využívajúcich zahraničné SIM karty na území Slovenska.

V tejto štúdii sme za turistu pokladali držitel’a SIM karty, ktorý na území SR vykonal z danej SIM karty telekomunikačné aktivity v rozmedzí $2-14$ dní počas kalendárneho roka 2016, pričom ich nemusel vykonat' v dňoch po sebe nasledujúcich. Kým spodná hranica časového intervalu môže (no nemusí) zachytávat' aspoň jedno prenocovanie, horná hranica by mala vylúčit' $z$ analýzy zahraničných rezidentov, ktorí na Slovensku zotrvávajú z rodinných či pracovných dôvodov. Treba však poznamenat', že takto nastavený filter je otvorený najmä v dolnom pásme intervalu, ked' zachytáva aj zahraničných užívatel'ov mobilnej siete v pohraničnom území, či pravidelnú tranzitnú dopravu. Sprísnenie minimálnej dížky pobytu na Slovensku, (napr. na dva po sebe idúce dni) by však vylúčilo aj početnú skupinu jednodňových turistov, resp. vylúčilo vel'kú čast' návštevníkov, ktorí nevykonávali telekomunikačné aktivity pravidelne každý deň svojho pobytu. Títo návštevníci (SIM karty) pritom tvorili $\mathrm{z}$ celkového počtu záznamov nadpolovičný podiel (54\%). Aplikáciou uvedenej podmienky na súbor zahraničných návštevníkov sme extrahovali 6027633 unikátnych návštevníkov s celkovým počtom 36418531 lokalizačných záznamov.

Pre komplexnejší pohl'ad na celkovú návštevnost' sme pracovali aj so súborom všetkých zahraničných SIM kariet, ktoré sa v roku 2016 prihlásili do mobilnej siete na území Slovenska. Takto definované záznamy SIM kariet sme označili ako „,zahraničných návštevníkov”, kým pre filtrované záznamy s dížkou pobytu $2-14$ dní sme použili označenie ,zahraniční turisti”. Prehl'ad použitých termínov a ich presnú definíciu udáva tabul'ka 1 .

Napriek zdanlivej jednoduchosti metodiky je pri interpretácii lokalizačných údajov mobilných zariadení dôležité si uvedomit' viaceré limity, ktoré vyplývajú z princípov prevádzky mobilnej siete, z nejednotnej metodológie a z technických limitov. Pokúsime sa upozornit' na tie najdôležitejšie:

- Počet SIM kariet nemožno spol'ahlivo stotožnit's počtom osôb (individuálnych užívatel'ov). Dôvodom je skutočnost', že nemôžeme predpokladat', že každý zahraničný návštevník disponuje mobilným zariadením a aktívne ho používa (napr. viacčlenná rodina môže na dovolenke využívat' iba jeden mobilný telefón). Rovnako nevieme z databázy vylúčit’ osoby využívajúce viaceré SIM karty.

- Problém viacnásobného prihlasovania do mobilnej siete. Zahraničný operátor môže mat' pri roamingových službách preferovanú siet', na ktorú sa SIM karta užívatel'a na území Slovenska pripája. Nie je však vylúčené, že držitel' SIM karty si túto siet' nastavuje manuálne, resp. pri nedostatočnom pokrytí signálu jedného z operátorov sa telefón automaticky pripojí na inú siet'. Tieto prípady však vzhl'adom na anonymný charakter identifikačných údajov nemožno vystopovat' a prepojit' (z technického dôvodu, ako aj z dôvodu citlivosti údajov a ochrany súkromia).

- Fiktívna návšteva uživatel'a vyvolaná pripojením $k$ mobilnej sieti slovenského operátora v pohraničných regiónoch Slovenska (tzv. hand-over noise). Pri nastavení pripojenia do mobilnej siete $\mathrm{v}$ automatickom režime sa mobilný telefón $\mathrm{v}$ prípade straty signálu domácej siete môže pripojit' do mobilnej siete v susednom štáte.

- Uživatel' SIM karty nemusi zodpovedat' držitel'ovi SIM karty, na základe ktorého sa určuje krajina registrácie. Štátnu príslušnost' návštevníka nemožno spol'ahlivo stotožnit' s krajinou registrácie držitel'a SIM karty. V tomto kontexte je potrebné 
osobitne zdôraznit', že medzi zahraničnými návštevníkmi môžu byt' zahrnutí aj občania Slovenska, využívajúci zahraničné SIM karty. Ide najmä o Slovákov pracujúcich v zahraničí, ktorých počet nie je zanedbatel'ný. Podl'a údajov Podnikatel'skej aliancie Slovenska (Kremský 2015), z vyše 300000 Slovákov, ktorí krátkodobo alebo dlhodobo pracujú v zahraničí, by malo byt' vyše 40 \% v Českej republike, štvrtina v Spojenom král'ovstve, 15 \% v Rakúsku a Nemecku, zvyšok v Írsku, Holandsku, Belgicku, Taliansku, Francúzsku, Švédsku a inde. Presný počet v niektorých krajinách nie je možné zistit', ked’že občania Slovenska v rámci vol'ného pohybu osôb na pracovnom trhu EU nie sú vždy povinní nahlasovat' úradom svoje st'ahovanie do zahraničia (Kremský 2015).

Tab. 1. Definícia použitých termínov v analýze

\begin{tabular}{l|l}
\hline Termín & Definícia \\
\hline $\begin{array}{l}\text { Telekomunikačná } \\
\text { aktivita }\end{array}$ & Hlasová, textová alebo obrazová aktivita SIM karty (mobilného zariadenia) \\
\hline $\begin{array}{l}\text { Zahraničný } \\
\text { návštevník }\end{array}$ & $\begin{array}{l}\text { Užívatel' SIM karty s krajinou registrácie inou ako Slovensko, ktorý bol prihlásený do } \\
\text { jednej zo sietí poskytujúcich roamingové služby na Slovensku (Slovak Telekom, Orange } \\
\text { Slovensko a O2 Slovakia) v roku 2016 a v analyzovanom období vykonal aspoń jednu } \\
\text { telekomunikačnú aktivitu. }\end{array}$ \\
\hline $\begin{array}{l}\text { Zahraničný } \\
\text { turista }\end{array}$ & $\begin{array}{l}\text { Užívatel' SIM karty s krajinou registrácie inou ako Slovensko, ktorý bol prihlásený do } \\
\text { jednej zo sietí poskytujúcich roamingové služby na Slovensku (Slovak Telekom, Orange } \\
\text { Slovensko a O2 Slovakia) a počas roka 2016 vykonal minimálne dve telekomunikaćné } \\
\text { aktivity v intervale 2 - 14 dní, pričom telekomunikačné aktivity nemuseli byt' realizova- } \\
\text { né v dňoch po sebe nasledujúcich. }\end{array}$ \\
\hline $\begin{array}{l}\text { Počet lokalizačných } \\
\text { záznamov } \\
\text { návštevníkov }\end{array}$ & $\begin{array}{l}\text { Počet zahraničných návštevníkov evidovaných za jeden kalendárny mesiac a okres. } \\
\text { Zahraničný návštevník môže byt' evidovaný v jednom kalendárnom mesiaci vo viace- } \\
\text { rých okresoch, vždy však maximálne jedenkrát. Zároveň môže byt' evidovaný v jednom } \\
\text { okrese vo viacerých kalendárnych mesiacoch, vždy však maximálne jedenkrát. }\end{array}$ \\
\hline $\begin{array}{l}\text { Počet lokalizačných } \\
\text { záznamov turistov }\end{array}$ & $\begin{array}{l}\text { Počet zahraničných turistov evidovaných za jeden kalendárny mesiac a okres. Zahranič- } \\
\text { ný turista môže byt' evidovaný v jednom kalendárnom mesiaci vo viacerých okresoch, } \\
\text { vždy však maximálne jedenkrát. Zároveň môže byt' evidovaný v jednom okrese vo } \\
\text { viacerých kalendárnych mesiacoch, vždy však maximálne jedenkrát. }\end{array}$ \\
\hline $\begin{array}{l}\text { Počet unikátnych } \\
\text { návštevníkov/ } \\
\text { turistov }\end{array}$ & $\begin{array}{l}\text { Počet zahraničných návštevníkov (zahraničných turistov) zaznamenaných minimálne } \\
\text { jedenkrát v mobilnej sieti na Slovensku v roku 2016. }\end{array}$ \\
\hline
\end{tabular}

Fiktívny príklad: Užívatel' SIM karty s krajinou registrácie v Nemecku sa rozhodol v auguste 2016 strávit’ dovolenku na Slovensku. Počas týždenného pobytu v Banskej Štiavnici, kde bol po celý čas ubytovaný, vykonal telekomunikačnú aktivitu v okresoch Bratislava IV, Nitra, Banská Štiavnica a Banská Bystrica. V každom z týchto okresov je evidovaný jedenkrát, aj ked’ sa v týchto okresoch mohol vyskytnút' viackrát počas sledovaného mesiaca. Hoci na svojej ceste pravdepodobne navštívil aj okres Zvolen, ked’že v rámci neho nevykonal telekomunikačnú aktivitu, nie je v tomto okrese a $\mathrm{v}$ danom mesiaci evidovaný.

- Vol’ná definícia pojmu turista. Prostredníctvom lokalizačných údajov mobilných telefónov vieme spol'ahlivo určit', že daná SIM karta (osoba) sa v daný čas nachádzala v určitom priestorovom polygóne (napr. v okrese). Označenie zahraničných návštevníkov pojmom ,zahraničný turista” je potrebné vnímat' v kontexte použitej metodiky a počty lokalizačných záznamov turistov sú len aproximáciou návštevnosti a nie jej presnou kvantifikáciou. 
- Ekonomická úroveň návštevníkov môže ovplyvnit’ frekvenciu využivania mobilného telefónu (Ahas et al. 2008). Hoci sa ceny za roamingové služby v ostatnom desat'ročí výrazne znížili, pre niektorých návštevníkov, najmä tých mimo EÚ, môžu zvýšené náklady na využívanie mobilnej siete predstavovat' určité obmedzenie. Ako ukazuje nedávny prieskum (European Commission 2018), obyvatelia EU stále využívajú mobilný telefón v zahraničí menej ako v ich domácej krajine.

V dôsledku uvedených limitov je pri interpretácii údajov potrebné pracovat' s nevyhnutnou mierou generalizácie a vnímat' lokalizačné údaje mobilných zariadení skôr z pozície zmysluplných indícií pre spoznanie reality, než ako vyčerpávajúci a presný obraz. Použitý filtračný algoritmus a obmedzená možnost' práce s neagregovanými údajmi neumožnili alternatívne metodické prístupy. Prezentované výsledky sú len jedným z množstva metodických prístupov, o ktorých by sme mohli uvažovat'. Použitie iných filtračných postupov by bolo nepochybne prospešné na dosiahnutie komplexnejšieho pohl'adu na možnosti lokalizačných údajov zahraničných užívatel'ov mobilnej siete, avšak vopred zadané parametre na extrahovanie „návštevníkov“ a „turistov“ pre spracovatel'skú spoločnost' (Market Locator SK) neumožňovali dodatočné korekcie pri filtrovaní záznamov.

\section{ODKIAL' PRICHÁDZAJÚ ZAHRANIČNÍ NÁVŠTEVNÍCI NA SLOVENSKO?}

V roku 2016 bolo v sieti troch najväčších mobilných operátorov zaznamenaných 14365194 unikátnych zahraničných užívatel'ov (návštevníkov), z čoho 6027633 užívatel'ov môžeme v zmysle uvedenej definície označit' ako unikátnych turistov. Z priestorového hl'adiska prichádzali zahraniční návštevníci zo 172 štátov a turisti zo 116 štátov sveta. V prípade zahraničných návštevníkov aj v prípade zahraničných turistov jednoznačne dominuje makroregión Európy $(97,8$ \% všetkých zahraničných návštevníkov a 98,3 \% turistov). Mimoeurópskych návštevníkov bolo viac ako 540 000, turistov viac ako 105000 . Z nich dominovali unikátni zahraniční návštevníci/turisti z Ázie (83,6 \% / 81,7 \%), d’alej z makroregiónu Oceánia $(5,1 \%$ / 4,8 \%), Južnej a Strednej Ameriky (4,9\% / 5,0 \%), Severnej Ameriky $(3,3 \% / 5,3 \%)$ a Afriky $(3,2 \% / 3,4 \%)$. Struktúru zahraničných návštevníkov/ turistov podl'a makroregiónov sveta zachytáva obr. 1 .

V štruktúre unikátnych zahraničných návštevníkov z Európy tvorili návštevníci zo susediacich štátov (Pol'sko, Česká republika a Mad'arsko) viac ako 60 \% podielu (obr. 2). Vo všeobecnosti navštevovali Slovensko najmä obyvatelia východnej Európy $(68 \%)$. Dominantný podiel unikátnych zahraničných návštevníkov z východnej Európy môžeme interpretovat' aj ako dôsledok polohy územia Slovenska na tranzitnom koridore východ - západ, resp. sever - juh. Zo západnej Európy smerovalo na Slovensko 21 \% všetkých európskych návštevníkov, predovšetkým z Nemecka a Rakúska, $\mathrm{v}$ najmenšom počte prichádzali z Luxemburska a Lichtenštajnska. Najpočetnejšiu skupinu zo severnej Európy zastupovali unikátni zahraniční návštevníci zo Spojeného král'ovstva (viac ako 410000 návštevníkov), najmenej početnú skupinu z Islandu (2 000 návštevníkov). Z južnej Európy dominovali návštevníci z Talianska. Takmer 120000 unikátnych zahraničných návštevníkov prišlo na Slovensko z Chorvátska a Slovinska. 

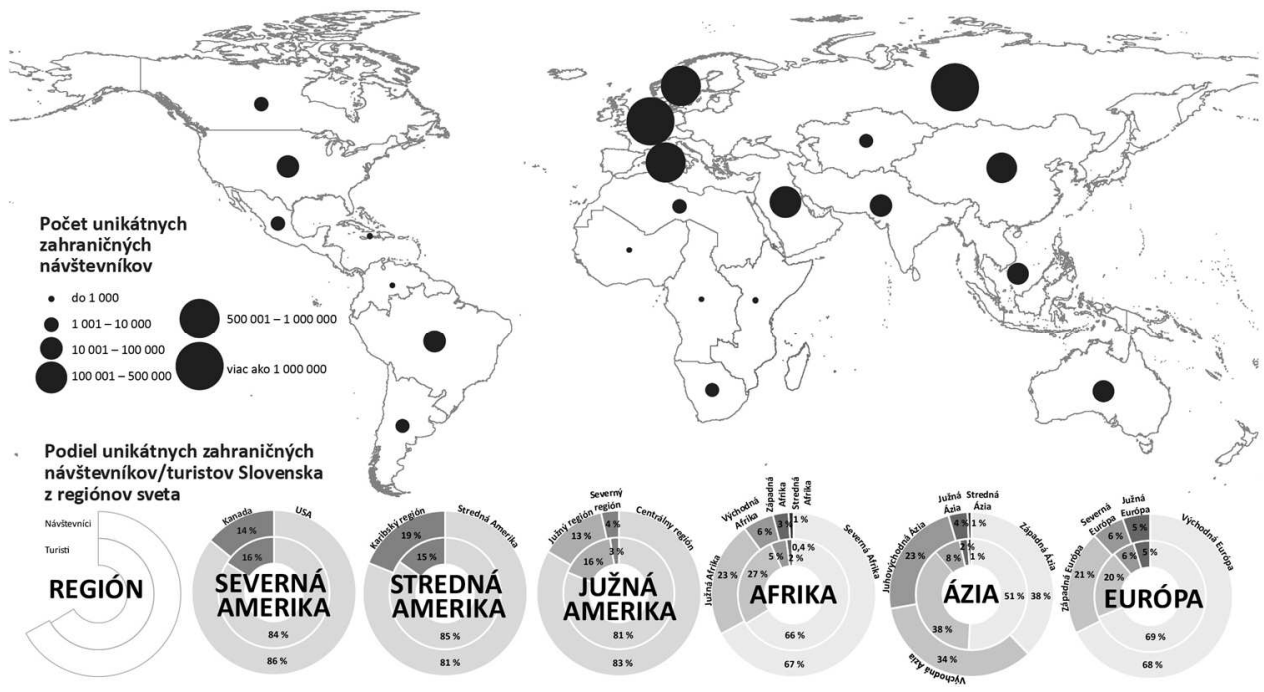

Obr. 1. Unikátni zahraniční návštevníci Slovenska v roku 2016 podl’a krajiny registrácie SIM karty z makroregiónov sveta

Klasifikácia makroregiónov vychádza z metodiky M49 podl’a OSN. Ruská federácia je podl’a nej zaradená do regiónu východná Európa. Viac ako 99,9\% unikátnych zahraničných návštevníkov/ turistov z makroregiónu Oceánia má krajinu registrácie Austráliu alebo Nový Zéland. Z Melanézie, Polynézie alebo Mikronézie prišlo na Slovensko 12 unikátnych zahraničných návštevníkov a žiaden turista. Zdroj údajov: Slovak Telekom (2017), Orange Slovensko (2017) a O2 Slovensko (2017), vlastné spracovanie.

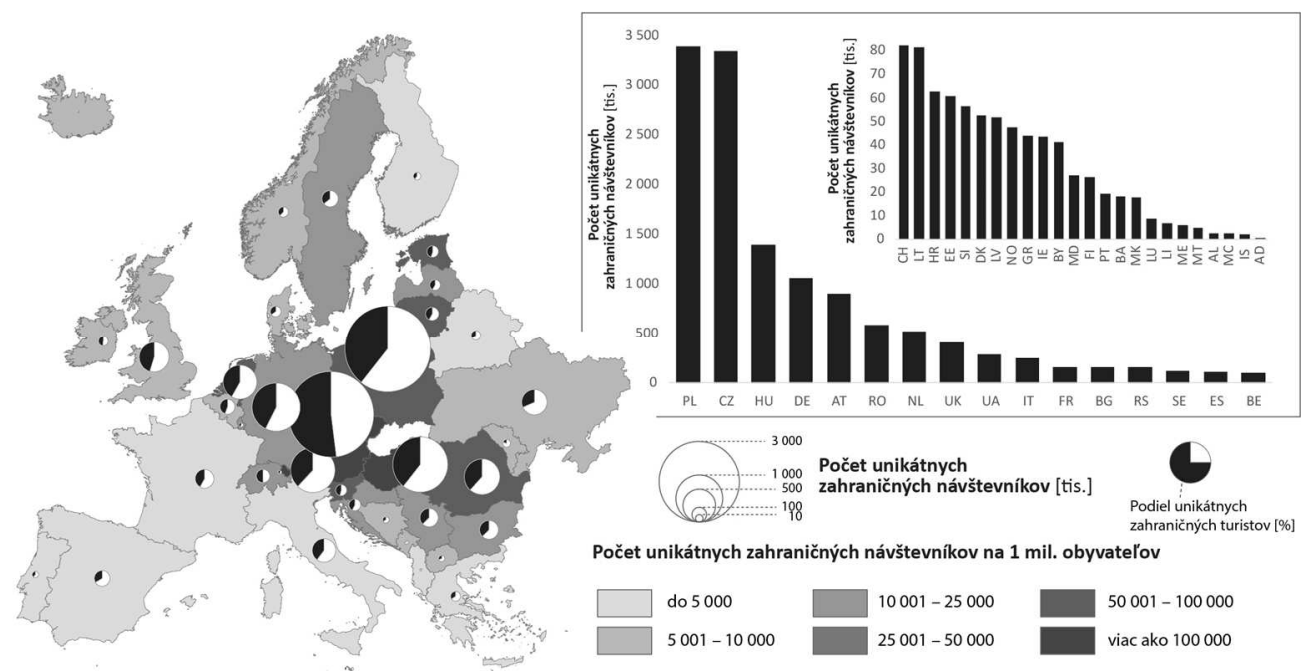

Obr. 2. Unikátni zahraniční návštevníci Slovenska v roku 2016 podl’a krajiny registrácie SIM karty z vybraných európskych štátov

Zdroj údajov: Slovak Telekom (2017), Orange Slovensko (2017) a O2 Slovensko (2017), vlastné spracovanie. 


\section{KAM SMERUJÚ ZAHRANIČNÍ NÁVŠTEVNÍCI NA SLOVENSKU?}

Pri pohl'ade na regionálne rozloženie počtu lokalizačných záznamov zahraničných návštevníkov na území Slovenska pozorujeme značné disproporcie (obr. 3). Okresy s najväčším výskytom zahraničných užívatel'ov slovenskej mobilnej siete vytvárajú kompaktný pás smerujúci od Bratislavy cez Považie a Žilinu, ktorý d'alej prechádza na Liptov a do Popradskej kotliny. Uvedenú koncentráciu pravdepodobne podmieňuje existencia nadradenej dopravnej infraštruktúry, ktorá $\mathrm{v}$ podobe dial'ničného a železničného koridoru vytvára najvýznamnejšie medzinárodné dopravné prepojenie na Slovensku. Výsledný obraz priestorového rozloženia zahraničných návštevníkov je tak do značnej miery podmienený tranzitnou dopravou, čoho dôkazom sú zvýšené koncentrácie evidovaných telekomunikačných aktivít zahraničných SIM kariet práve v okresoch na dôležitých spojniciach v smere sever - juh (Čadca - Kysucké Nové Mesto - Žilina, Svidník - Prešov - Košice okolie, Senica - Malacky - Bratislava, Banská Bystrica - Zvolen - Vel'ký Krtíš).

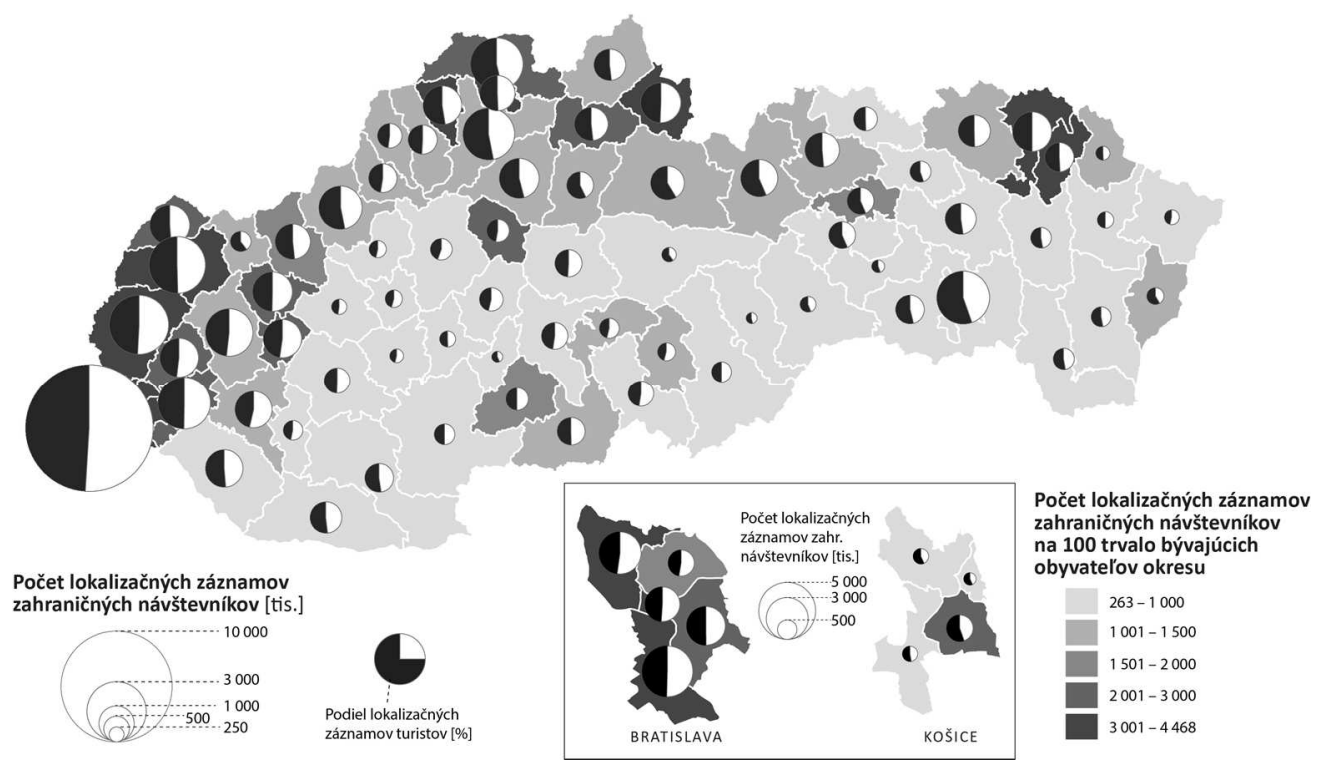

Obr. 3. Počet lokalizačných záznamov zahraničných návštevníkov v roku 2016 v okresoch Slovenska

Zdroj údajov: Slovak Telekom (2017), Orange Slovensko (2017) a O2 Slovensko (2017), vlastné spracovanie.

Regiónom s najvyššou koncentráciou počtu lokalizačných záznamov zahraničných návštevníkov je jednoznačne Bratislava, na ktorej území bolo zaregistrovaných vyše $19 \%$ lokalizačných záznamov. Na porovnanie, metropola východu Košice - zaznamenala v roku 2016 len niečo vyše 3 \% lokalizačných záznamov zahraničných návštevníkov. Okrem mestských okresov Bratislavy zaznamenali vysoký počet lokalizačných záznamov okresy Malacky, Senica a Senec, čím umocňujú t'ažisko koncentrácie zahraničných návštevníkov do juhozápadnej časti Slovenska. Bratislavský a Trnavský samosprávny kraj sústred’ujú vyše 43 \% lokalizačných záznamov zahraničných návštevníkov. 
Z hl'adiska sezónnosti je návštevnost' charakterizovaná ako značne nerovnomerná, ked’že vyše $35 \%$ lokalizačných záznamov návštevníkov pripadá na mesiace júl - september (obr. 4). Jarné a jesenné obdobie zaznamenalo približne podobnú úroveň návštevnosti, na zimné mesiace (január - marec) pripadá najmenší podiel návštevníkov (18 \%). Pri bližšom pohl'ade na úrovni okresov pozorujeme, že väčšina okresov (71) zaznamenala maximum návštevnosti v mesiaci august. Druhá polovica letnej dovolenkovej sezóny sa tak profiluje ako dominantnejšia.

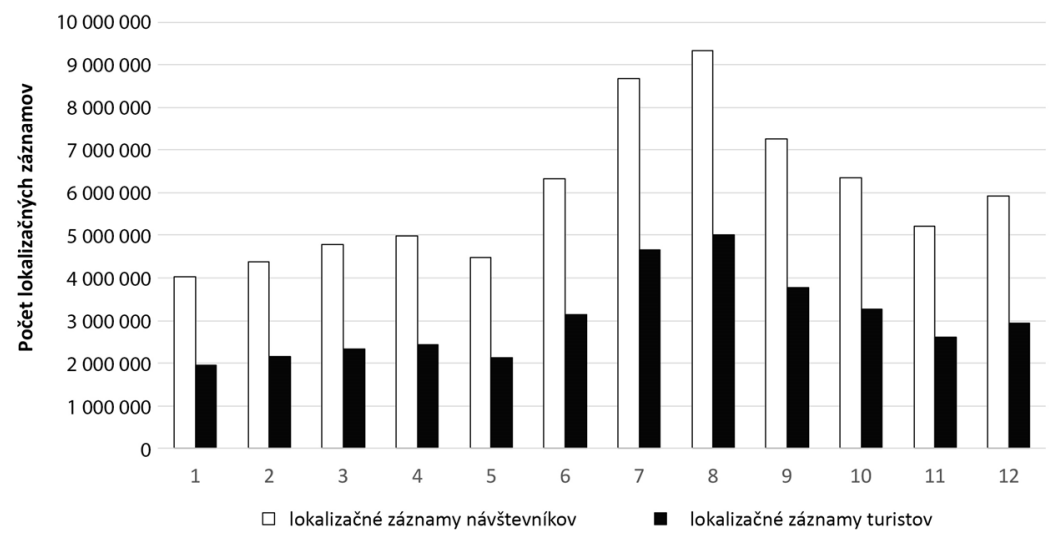

Obr. 4. Počet lokalizačných záznamov návštevníkov a turistov na Slovensku $\mathrm{v}$ jednotlivých mesiacoch roka 2016

Zdroj údajov: Slovak Telekom (2017), Orange Slovensko (2017) a O2 Slovensko (2017), vlastné spracovanie.

Pri interpretácii priestorového rozloženia zahraničnej návštevnosti na Slovensku na základe lokalizačných dát mobilnej siete je potrebné upozornit' na rozdiel medzi charakterom nefiltrovaných údajov (návštevníci) a filtrovaných údajov (turisti). Ako sme naznačili v metodike, ciel’om použitia filtrovaných údajov je aspoň čiastočne eliminovat' vplyv tranzitnej dopravy a cezhraničných prepojení na slovenskú mobilnú siet'. Obr. 5 ilustruje rozdiel v počte lokalizačných záznamov na príklade užívatel'ov mobilnej siete registrovaných na Ukrajine v okrese Svidník, ktorý predstavuje typický tranzitný región s len málo využitým potenciálom pre turizmus. Počty filtrovaných záznamov (turistov) vykazujú podobnú sezónnu variabilitu ako počty všetkých zaznamenaných návštevníkov. Ako však naznačujú absolútne hodnoty lokalizačných záznamov turistov, ani filtrovanie údajov neprináša úplne spol'ahlivý obraz turistickej návštevnosti. V priemere 1500 turistov mesačne z Ukrajiny v okrese Svidník je pravdepodobne z hl'adiska objektívnych podmienok v okrese nadhodnotený údaj. Podmienka pripojenia užívatel'a SIM karty v dížke $2-14$ dní síce zredukovala pôvodný počet lokalizačných záznamov o takmer polovicu $(49,2 \%)$, napriek tomu pravdepodobne neodzrkadl'uje skutočný počet turistov. Na limity zvoleného algoritmu poukazuje aj skutočnost', že podiel lokalizačných záznamov turistov nezaznamenal výraznejšiu priestorovú variabilitu, ked' pri okresoch s „tranzitných“ charakterom (napr. Svidník a Senica) sa nepreukázala očakávaná prevaha nefiltrovaných lokalizačných záznamov. Je preto dôležité brat' objemy evidovaných turistov s interpretačnou rezervou a sústredit' sa skôr na sezónnu 
variabilitu návštevnosti. V d'alšej časti analýzy pracujeme výlučne s lokalizačnými záznamami turistov.

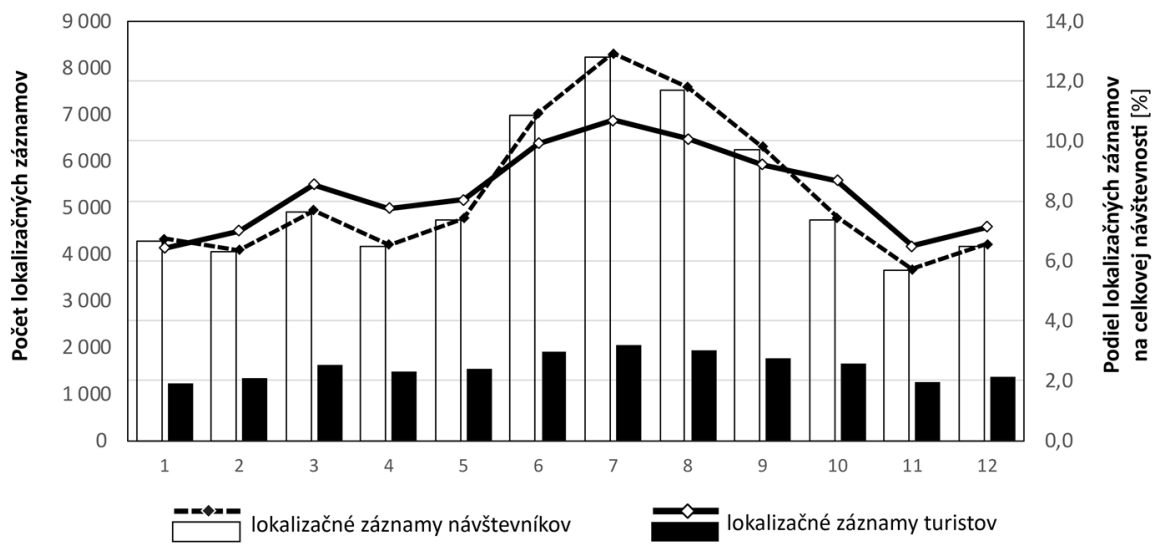

Obr. 5. Počet lokalizačných záznamov užívatel’ov SIM kariet s registráciou na Ukrajine v okrese Svidník za mesiace roka 2016: porovnanie počtu lokalizačných záznamov návštevníkov (nefiltrované záznamy) a turistov (filtrované záznamy)

Zdroj údajov: Slovak Telekom (2017), Orange Slovensko (2017) a O2 Slovensko (2017), vlastné spracovanie.

Pri pohl'ade na krajinu pôvodu (registrácie SIM karty) dominujú najmä turisti zo susedných krajín, ktorí tvorili $67 \%$ z celkového počtu unikátnych zahraničných turistov v roku 2016. Nie prekvapivo dominujú užívatelia mobilného zariadenia z Česka (28 \%) a Pol'ska (22 \%). Zahraniční turisti z Mad'arska tvorili $9 \%$ a významnejší podiel na návštevnosti dosiahli ešte užívatelia mobilnej siete z Nemecka (7\%) a Rakúska (6\%). Z hl'adiska priestorovej distribúcie zaznamenali najväčší počet lokalizačných záznamov predovšetkým prihraničné okresy (obr. 6). Táto skutočnost' odráža intenzívne cezhraničné väzby, ale do určitej miery môže byt' skreslená presahom mobilnej siete do susedných krajín. Aj napriek uvedenému obmedzeniu sme však schopní identifikovat' regióny s nadpriemernou návštevnost’ou z jednotlivých krajín. Pri hodnotení výsledkov je však potrebné brat' do úvahy širší priestorový obraz návštevnosti. Ako dokumentujeme na príklade držitel'ov SIM karty registrovaných v Českej republike (zaznamenaných vyše 10 mil. lokalizačných záznamov), celkový počet evidovaných telekomunikačných aktivít sa znižuje v smere západ - východ a rovnako sa zmenšuje aj amplitúda návštevnosti počas roka. Napriek ,znečisteniu” údajov cezhraničnými pripojeniami môžeme pozorovat' výrazné sezónne vyprofilovanie návštevnosti, ktorá kulminuje v júli a v auguste a sezónne minimá dosahuje v máji a v novembri (obr. 7).

Na rovnakej vzorke šiestich okresov, ktoré sme vybrali tak, aby pokrývali tranzitné aj turistické regióny, ako aj západné a východné časti krajiny, môžeme ilustrovat' priebeh návštevnosti z ostatných susediacich krajín a interpretovat' filtrované dáta o návštevnosti. Ako môžeme pozorovat' na značne diferencovanom počte lokalizačných záznamov turistov, ako aj ich sezónnom rozdelení, pri interpretácii výsledkov je potrebné si všímat' lokálne sezónne výkyvy, ktoré môžu indikovat' reálnu návštevnost'. 

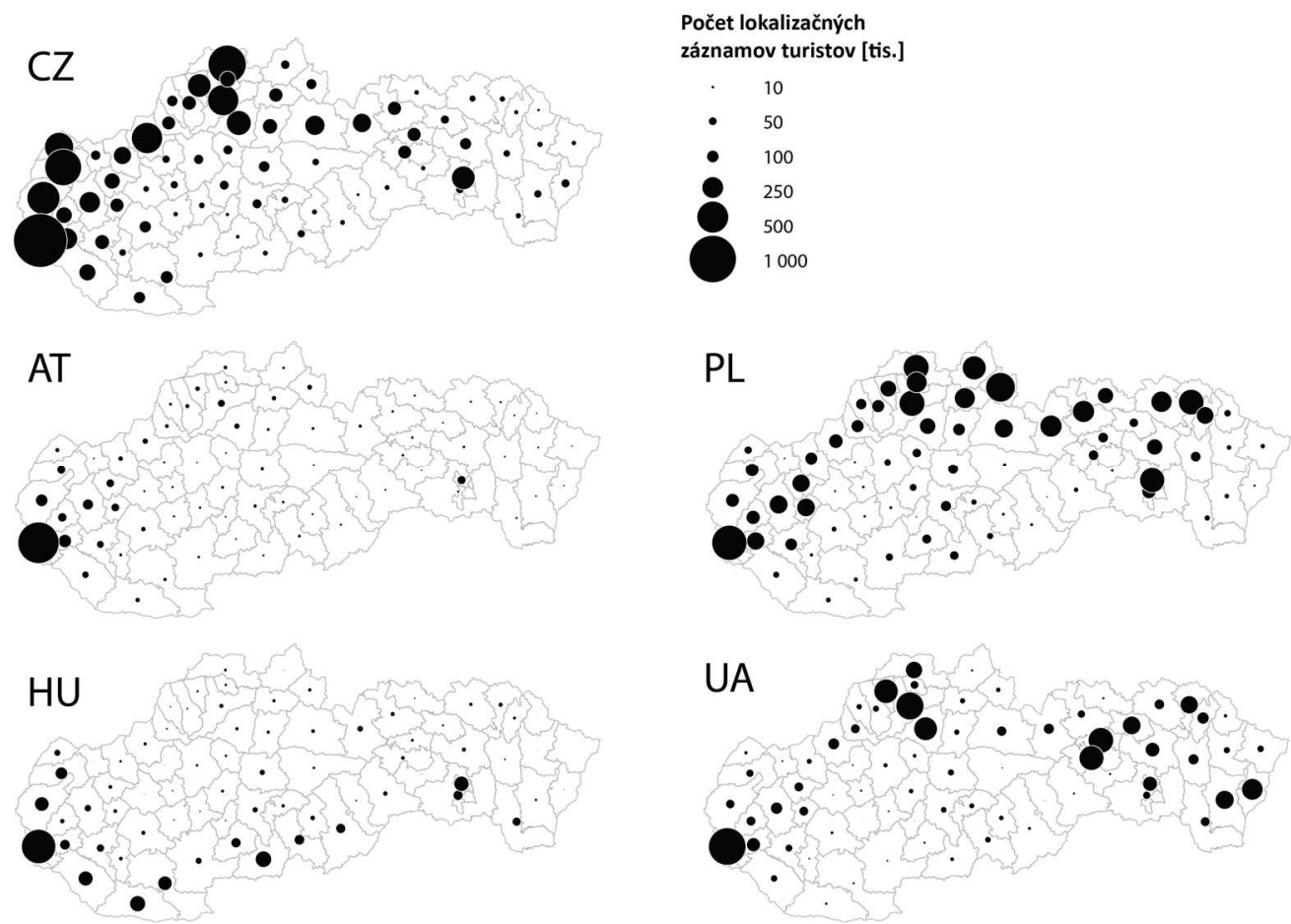

Obr. 6. Počet lokalizačných záznamov turistov z vybraných krajín v roku 2016 v okresoch Slovenska

Použité skratky štátov: CZ - Česká republika, AT - Rakúsko, HU - Mad'arsko, PL - Pol’sko, UA - Ukrajina

Zdroj údajov: Slovak Telekom (2017), Orange Slovensko (2017) a O2 Slovensko (2017), vlastné spracovanie.

Pri turistoch z Pol'ska pozorujeme početnejšie lokalizačné záznamy v okresoch Poprad a Liptovský Mikuláš v mesiacoch január a február, ktorá pravdepodobne súvisí so zimnou lyžiarskou sezónou na Liptove a v Tatrách. Kulminácia návštevnosti v letných mesiacoch nie je prekvapivá, zaujme však výrazná dominancia návštevnosti v auguste (o $32 \%$ pol'ských turistov viac ako v júli).

Turisti s krajinou registrácie mobilného zariadenia na Ukrajine majú výrazne vyššiu návštevnost' v okresoch Liptovský Mikuláš a Poprad v mesiaci január, čo pravdepodobne súvisí s trávením dovolenky počas pravoslávnych sviatkov. Región Tatier je pritom tradične ciel'om návštevníkov z východnej Európy a Ruska. Sezónne maximá v letných mesiacoch a začiatkom jesene v okresoch Žilina a Spišská Nová Ves však takú jednoznačnú interpretáciu neponúkajú. Vzhl'adom na skutočnost', že podobnú sezónnu návštevnost' zaznamenali aj d'alšie okresy, sa ako jedno z možných vysvetlení ponúka pobyt sezónnych pracovníkov.

Návštevnost' turistov z Rakúska sa regionálne výrazne koncentrovala do Bratislavy (36 \%), v okresoch Senica a Žilina kulminuje v letných mesiacoch a môže súvisiet' so zvýšenou tranzitnou dopravou naprieč Slovenskom v rámci dovolenkového tranzitu, mierne zvýšené počty lokalizačných záznamov turistov v Tatrách a na Spiši v mesiaci august môžu byt' výsledkom kulminovania dovolenkových 
aktivít. Podobnú situáciu pozorujeme aj pri lokalizačných záznamoch turistov z Mad'arska, ktorých telekomunikačná aktivita $\mathrm{v}$ letných mesiacoch bola zaznamenaná vo výraznej miere práve v okrese Poprad, zatial' čo v susednom okrese Liptovský Mikuláš je nárast lokalizačných záznamov len vel'mi mierny. Uvedené zistenie by sme mohli interpretovat' ako väčšie uprednostnenie regiónu Vysokých Tatier pred Liptovom u mad'arských návštevníkov. V zimných mesiacoch však oba uvedené okresy $\mathrm{v}$ počte lokalizačných aktivít prekonáva okres Banská Bystrica (4 000 záznamov vo februári a 2800 v marci).
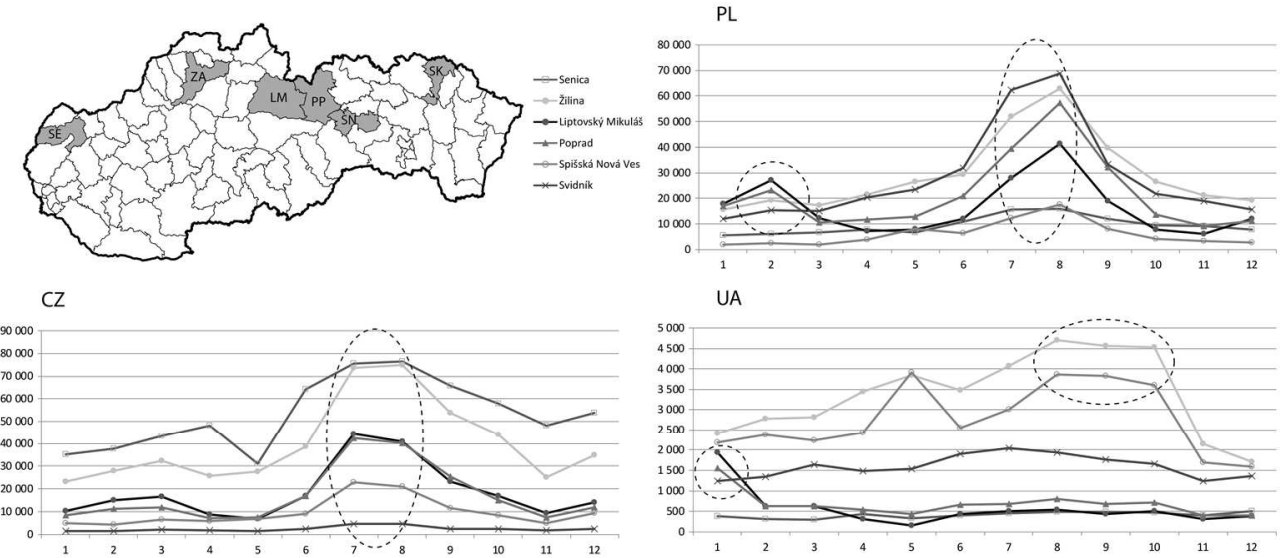

UA

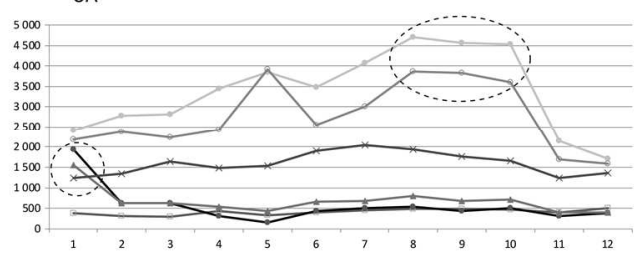

AT

$\mathrm{HU}$
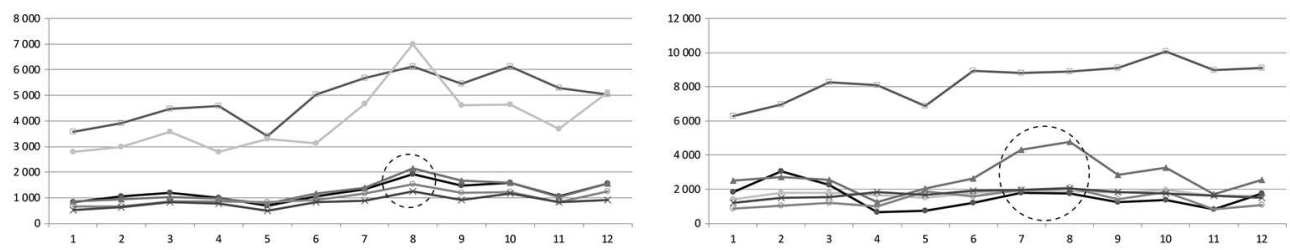

Obr. 7. Sezónna variabilita počtu lokalizačných záznamov turistov zo susedných krajín v roku 2016 vo vybraných okresoch na Slovensku

Použité skratky okresov: SE - Senica, ZA - Žilina, LM - Liptovský Mikuláš, PP - Poprad, SN - Spišská Nová Ves, SK - Svidník

Zdroj údajov: Slovak Telekom (2017), Orange Slovensko (2017) a O2 Slovensko (2017), vlastné spracovanie.

Pri analýze priestorového rozmiestnenia lokalizačných záznamov turistov z ostatných európskych krajín je interpretácia jednoduchšia, pretože nie je zatažená skreslením v prihraničných oblastiach. Na obr. 8 môžeme pozorovat' koncentráciu lokalizačných záznamov turistov $\mathrm{z}$ vybraných štátov. $\mathrm{Z}$ uvedenej vzorky početne dominujú zahraniční turisti z Nemecka, najmenšiu početnost' (koncentrovanú skoro výhradne do Bratislavy) zaznamenali užívatelia mobilnej siete z USA. Na uvedených príkladoch môžeme vhodne dokumentovat' aj sezónne špecifiká návštevnosti. Kým pre turistov zo Spojeného královstva, Francúzka či Nemecka pozorujeme kulminovanie návštevnosti $\mathrm{v}$ letných mesiacoch (najmä $\mathrm{v}$ auguste), pri turistoch z Ruska je ročný prierez návštevnosti ovel’a vyrovnanejší. Na priložených príkladoch môžeme pozorovat' aj odlišný charakter návštevnosti Rusov v okrese Poprad 
a Piešt’any. Kým v okrese Poprad dominujú lokalizačné záznamy turistov z Ruska najmä v januári, $v$ Piešt’anoch je ich návštevnost' celoročne vyrovnaná. Môžeme tak dokumentovat' rozdielny charakter kúpel'ného a horského regiónu cestovného ruchu, ktorého sezónne vzory databáza zahraničných užívatel'ov mobilnej siete vhodne zachytáva. Príkladom časovo-priestorovej lokalizácie, ktorá nezodpovedá tradičnému obrazu turistickej návštevnosti, je pohl'ad na užívatel'ov mobilných telefónov s krajinou registrácie v Srbsku. V tejto skupine zahraničných turistov bol zaznamenaný celoročný rast počtu lokalizačných záznamov, ktorý kulminoval v novembri roka 2016. Pravdepodobne ide o sezónnych (či trvalých) pracovníkov, ked’že medzi lokality ich najväčšej koncentrácie patrili regióny Galanty, Trnavy a okresy Bratislavského kraja.

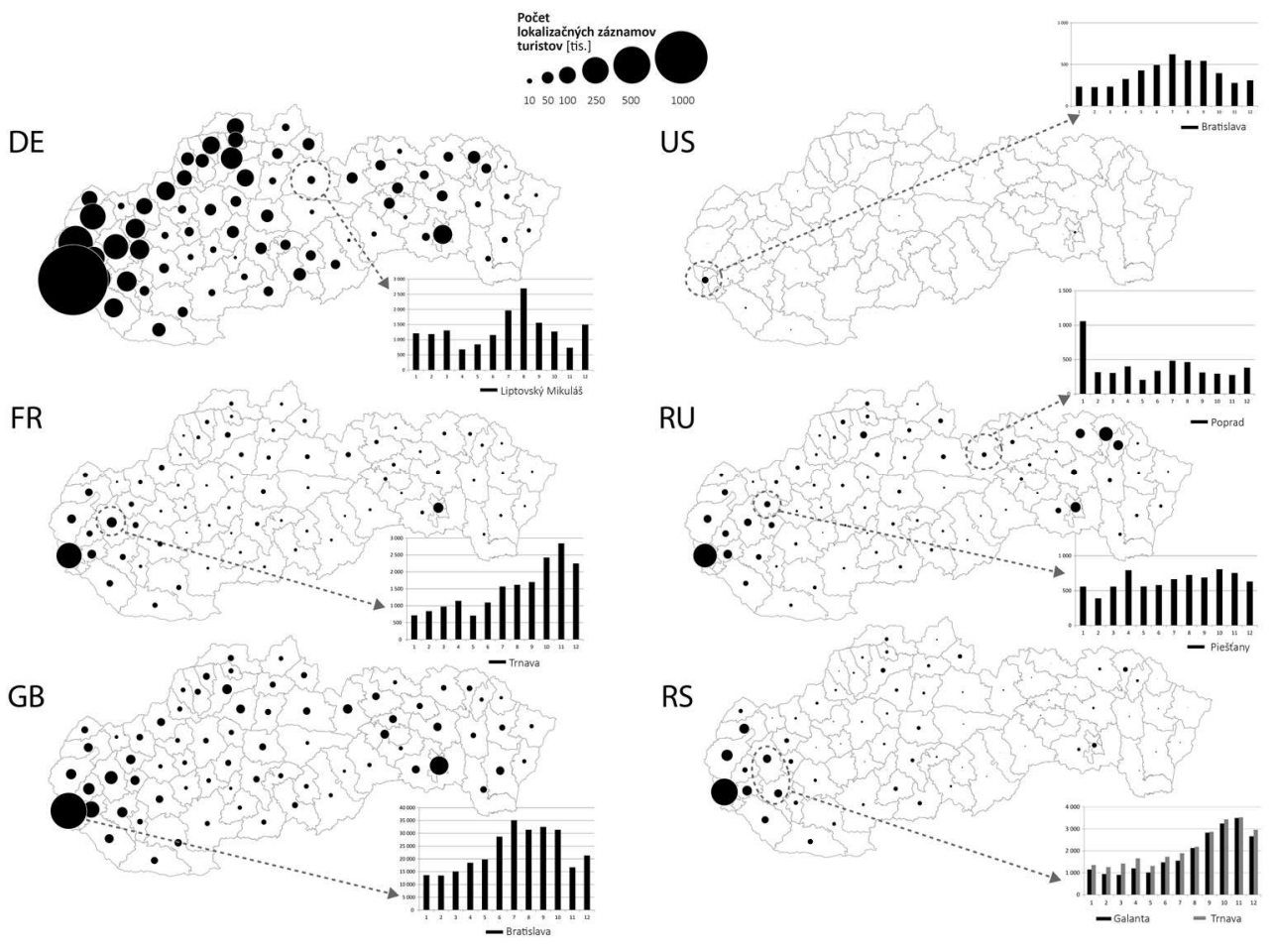

Obr. 8. Počet lokalizačných záznamov turistov z vybraných krajín v roku 2016 v okresoch Slovenska a príklady sezónnej variability návštevnosti vo vybraných okresoch

Použité skratky štátov: DE - Nemecko, US - Spojené štáty Americké, FR - Francúzko, RU - Rusko, GB - Spojené královstvo, RS - Srbsko.

Zdroj údajov: Slovak Telekom (2017), Orange Slovensko (2017) a O2 Slovensko (2017), vlastné spracovanie.

\section{LOKALIZAČNÉ ÚDAJE MOBILNÝCH ZARIADENÍ V KONTEXTE ŠTATISTIKY O POČTE PRENOCOVANÍ ZAHRANIČNÝCH NÁVŠTEVNÍKOV}

Pri uvažovaní nad využitím lokalizačných údajov mobilnej siete sa prirodzene ponúka možnost' presného sledovania návštevnosti v jednotlivých regiónoch, najmä v kontexte neúplnej evidencie prenocovaní. Podl'a evidencie Štatistického úra- 
du Slovenskej republiky (ŠÚ SR 2017) bolo v roku 2016 registrovaných 2027009 zahraničných návštevníkov v ubytovacích zariadeniach cestovného ruchu, zatial' čo identifikovaný počet unikátnych turistov prostredníctvom mobilnej lokalizácie dosiahol 3-násobne väčšiu úroveň. Porovnanie lokalizačných údajov mobilných zariadení s oficiálnou štatistikou o ubytovacích výkonoch je však značne problematické, vzhl'adom na odlišný mechanizmus oboch spôsobov evidencie. Zatial' čo inštitucionálne údaje sa vzt’ahujú na lokalitu prenocovania, dáta mobilnej lokalizácie zaznamenávajú pohyb návštevníkov $\mathrm{v}$ priestore $\mathrm{v}$ momente ich telekomunikačnej aktivity. Preto je potrebné sa vyhnút' priamemu porovnaniu absolútnych hodnôt a zamerat' sa na rozloženie návštevnosti počas roka. Zhodný časový priebeh oboch údajových zdrojov by mohol naznačovat' ich vzájomnú prepojenost' a do určitej miery aj relevantnost'. Príkladom je štúdia z Estónska (Ahas et al. 2008), ktorá preukázala vysokú priestorovú a časovú koreláciu medzi počtom ubytovaných zahraničných turistov a počtom telekomunikačných záznamov zahraničných užívatel'ov mobilnej siete.

Pri porovnaní ubytovacej štatistiky a údajov mobilnej lokalizácie pozorujeme podobný sezónny priebeh návštevnosti (obr. 9). Počet návštevníkov v ubytovacej štatistike od januára do augusta rastie a po zvyšok roka klesá; vývoj počtu lokalizačných záznamov turistov podl'a mobilnej lokalizácie sa od tohto trendu líši len medzimesačným poklesom v máji a nárastom $v$ decembri. Kým nárast počtu zaznamenaných turistov z mobilnej lokalizácie v decembri môže súvisiet' s migráciou Slovákov žijúcich v zahraničí na vianočné sviatky na Slovensko, sezónne minimum v máji však jednoznačnú interpretáciu neponúka.

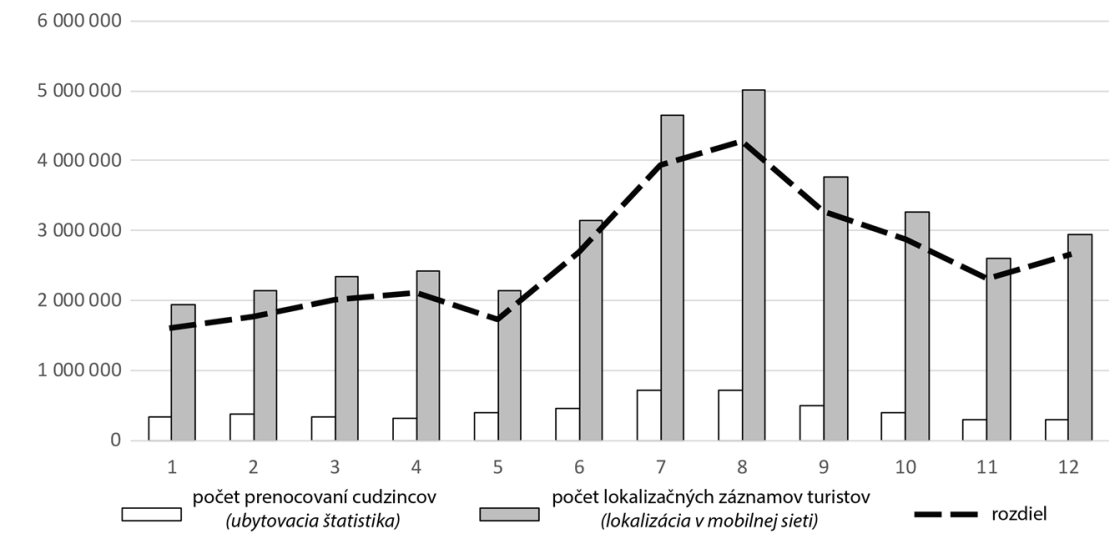

Obr. 9. Porovnanie sezónneho priebehu návštevnosti z pohl'adu počtu zahraničných návštevníkov v ubytovacích zariadenia (ubytovacia štatistika) a počtu lokalizačných záznamov turistov (pasívne lokalizačné údaje mobilnej siete) v roku 2016

Zdroj údajov: ŠÚ SR (2017), Slovak Telekom (2017), Orange Slovensko (2017) a O2 Slovensko (2017), vlastné spracovanie.

Pri porovnaní údajov z hl'adiska zdrojových krajín zahraničnej návštevnosti pozorujeme výraznú koreláciu (obr. 10). Táto skutočnost’ môže naznačovat', že údaje z mobilnej siete prinášajú obdobné proporčné rozdelenie návštevníkov podl'a krajiny pôvodu ako ubytovacia štatistika. Je zaujímavé, že aj pri málo početných skupinách zahraničných turistov sa tesnost' závislosti príliš neznižuje. Zhodný sezónny 
priebeh ubytovacej štatistiky a počtu lokalizačných záznamov turistov môžeme sledovat' aj na úrovni okresov. Obr. 11 a 12 znázorňujú vývoj lokalizačných záznamov turistov z Česka v okrese Liptovský Mikuláš a turistov z Izraela v okrese Piešt’any. V oboch prípadoch môžeme pozorovat' zhodný sezónny priebeh oboch ukazovatel'ov návštevnosti, hoci ide o pomerne rozdielne situácie horského a kúpel'ného turizmu.

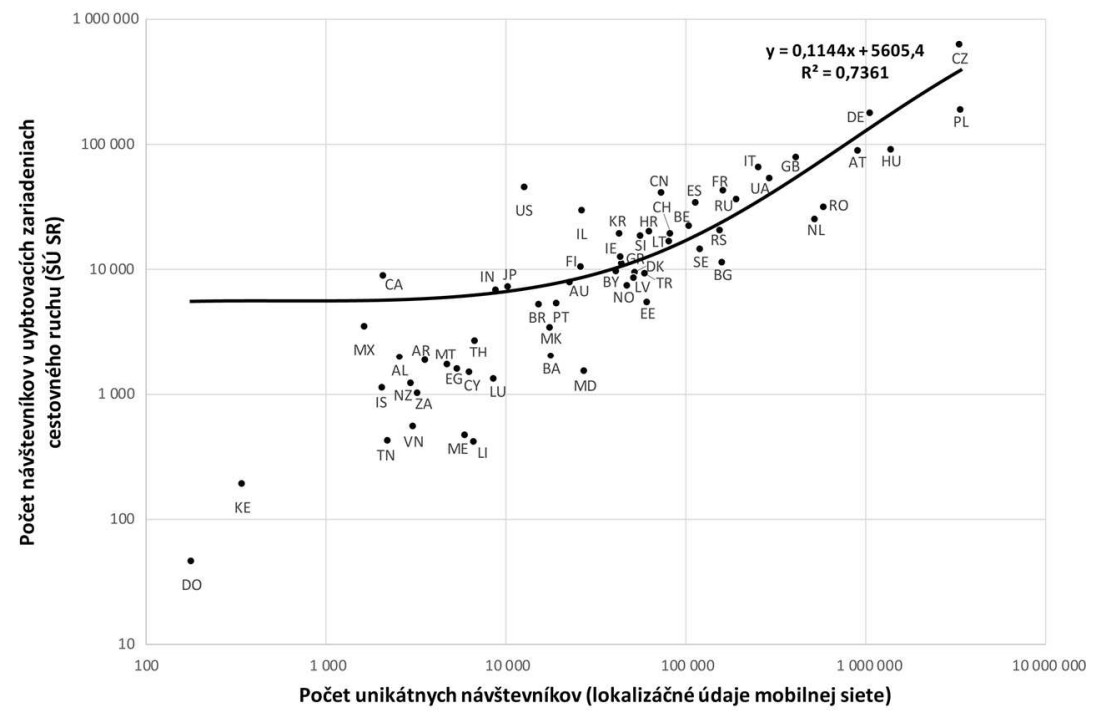

Obr. 10. Závislost' počtu návštevníkov v ubytovacích zariadeniach a počtu unikátnych návštevníkov podl'a krajiny registrácie SIM karty v roku 2016

Dvojpísmenové kódové označenia krajín vychádza zo štandardu WIPO ST. 3.

Zdroj údajov: ŠÚ SR (2017), Slovak Telekom (2017), Orange Slovensko (2017) a O2 Slovensko (2017), vlastné spracovanie.

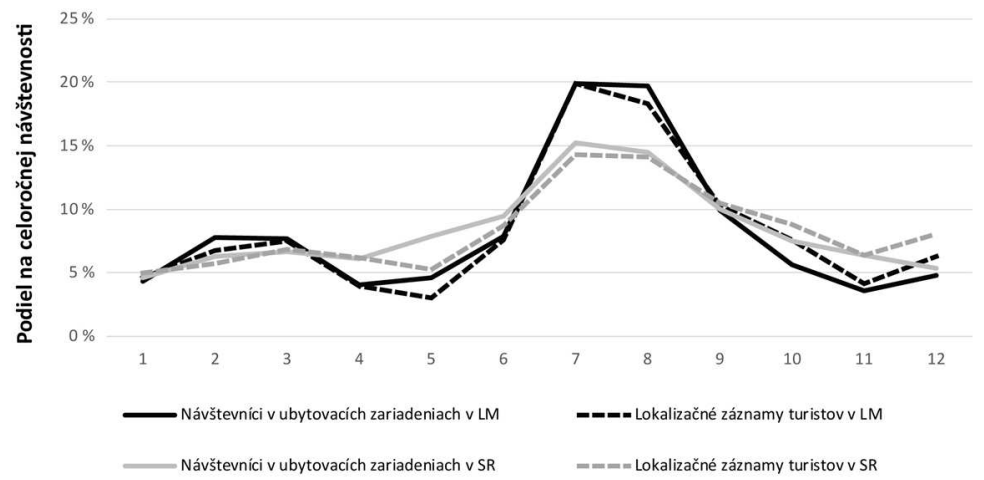

Obr. 11. Porovnanie sezónneho priebehu návštevnosti v mesiacoch roku 2016 podl’a počtu ubytovaných (ubytovacia štatistika) a počtu lokalizačných záznamov turistov (pasívne lokalizačné údaje mobilnej siete) z Česka v okrese Liptovský Mikuláš (LM) a na Slovensku (SR)

Zdroj údajov: ŠÚ SR (2017), Slovak Telekom (2017), Orange Slovensko (2017) a O2 Slovensko (2017), vlastné spracovanie 
Avšak pri pohl'ade na celý súbor okresov sa korelácia medzi počtom návštevníkov v evidovaných $\mathrm{v}$ ubytovacích zariadeniach a turistov mobilnej lokalizácie rozpadá (obr. 13). Dôvodom sú predovšetkým prihraničné okresy situované na hlavných tranzitných koridoroch - napríklad Bratislava IV, Svidník, Senica či Čadca, kde počet lokalizačných záznamov turistov výrazne prevyšuje ubytovacie štatistiky.

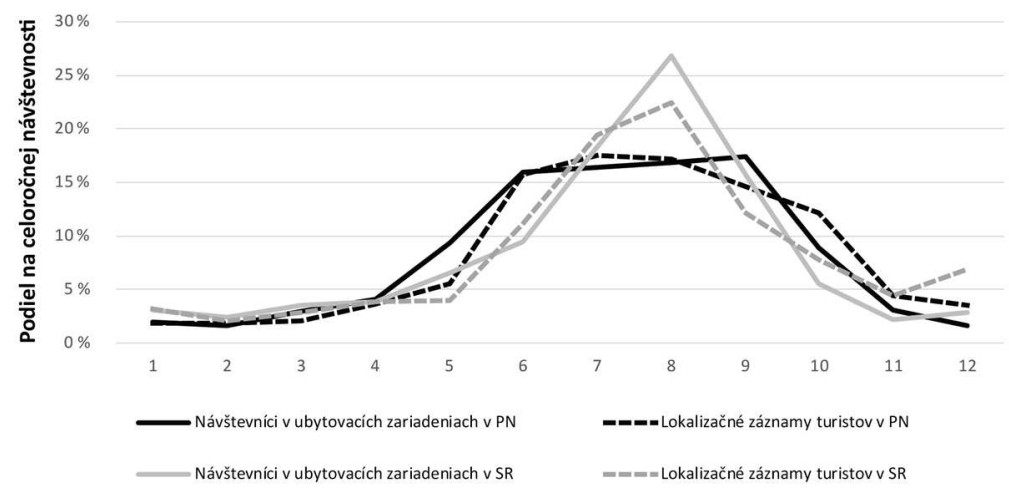

Obr. 12. Porovnanie sezónneho priebehu návštevnosti v mesiacoch roku 2016 podl'a počtu ubytovaných (ubytovacia štatistika) a počtu lokalizačných záznamov turistov (pasívne lokalizačné údaje mobilnej siete) z Izraela v okrese Piešt’any (PN) a na Slovensku (SR)

Zdroj údajov: ŠÚ SR (2017), Slovak Telekom (2017), Orange Slovensko (2017) a O2 Slovensko (2017), vlastné spracovanie.

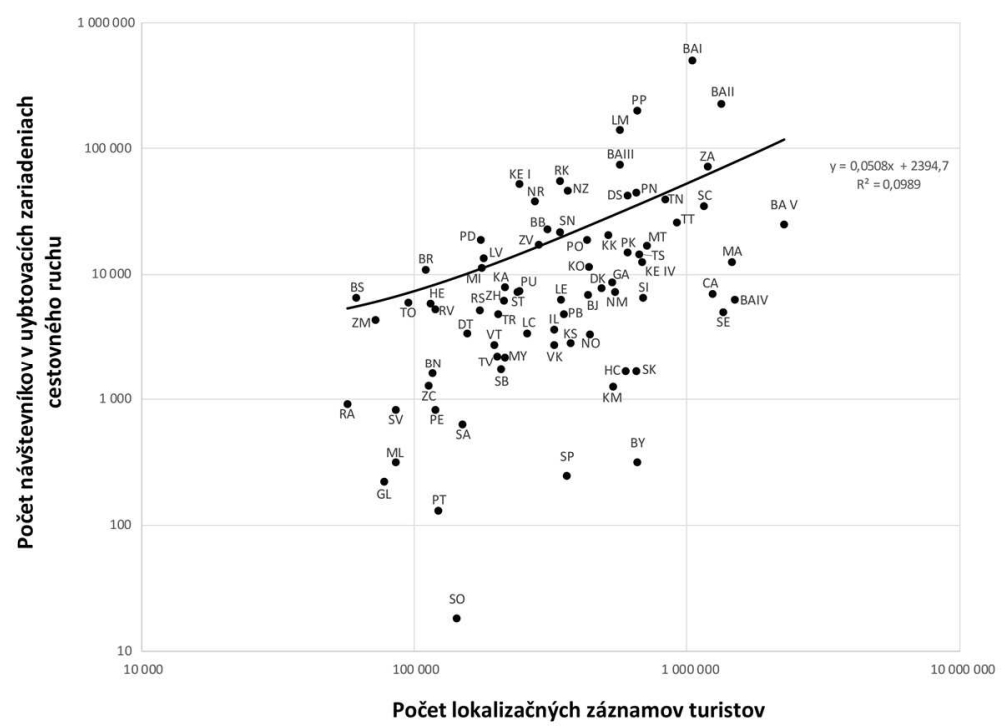

Obr. 13. Závislost' počtu návštevníkov v ubytovacích zariadeniach a počtu lokalizačných záznamov turistov podl'a okresov Slovenska v roku 2016

Zdroj údajov: ŠÚ SR (2017), Slovak Telekom (2017), Orange Slovensko (2017) a O2 Slovensko (2017), vlastné spracovanie 


\section{ZÁVER}

Rozvoj informačno-komunikačných technológií priniesol celý rad dôsledkov pre štúdium l’udského správania a priestorovej mobility. Vd'aka zberu georeferencovaných údajov prostredníctvom mobilnej siete sa ponúkajú nové možnosti na porozumenie mobility a vzorov časovo-priestorového správania jednotlivcov. V pilotnej štúdii sme sa zamerali na analýzu priestorovej, časovej a štruktúrnej dimenzie zahraničnej návštevnosti na Slovensku s využitím anonymizovaných pasívnych lokalizačných údajov mobilnej siete troch najväčších slovenských operátorov.

Pri súčasnej vysokej penetrácii mobilných zariadení v celosvetovej populácii prinášajú lokalizačné údaje mobilnej siete bezprecedentnú možnost' zachytenia pohybu zahraničných návštevníkov na území Slovenska. V pilotnej štúdii boli údaje priestorovo agregované do úrovne okresov, ale technické parametre mobilnej lokalizácie umožňujú íst' do ovel’a podrobnejšej priestorovej mierky (až na úroveň buniek mobilnej siete). Identifikácia zahraničných návštevníkov na základe telekomunikačnej aktivity je presným záznamom o lokalizácii užívatel’a SIM karty v území pokrytom signálom domácich operátorov. Problematickejšie je však extrahovanie zmysluplných záznamov o pohybe turistov na území Slovenska.

Výsledky analýzy odhalili, že sezónne vzorce návštevnosti závisia od mierky pohl'adu (cf. Buhalis 2000, Framke 2002 a Raun et al. 2016). Kým pri porovnaní štruktúry návštevníkov podla krajiny pôvodu na celorepublikovej úrovni pozorujeme vysokú koreláciu s údajmi zaznamenanými v ubytovacích zariadeniach, regionálny pohlaad prináša značne diferencovaný (nekompatibilný) obraz návštevnosti. Diferencie sú zapríčinené predovšetkým obmedzenou schopnost' filtrovat' skutočných účastníkov cestovného ruchu od tranzitných návštevníkov a cezhraničných pripojení zo susediacich krajín. Riešením by bola analýza priebehu telekomunikačných aktivít počas dňa. Identifikácia denných a nočných lokalít individuálnych užívatel'ov by pravdepodobne umožnila jednoznačnejšie priradenie miesta pobytu (ubytovania). Bez týchto dodatočných informácií je odhad počtu návštevníkov, resp. turistov, limitovaný technickými špecifikami databázy a konštrukciou vhodných algoritmov (očistenie od záznamov tranzitných návštevníkov a cezhraničných pripojení).

Napriek tomu možno mobilné dáta považovat' za užitočné pre analýzu sezónnych (časových) aspektov turizmu na Slovensku a preferencií konkrétnych regiónov Slovenska návštevníkmi z jednotlivých krajín. Niektoré zistenia zodpovedajú všeobecnej priestorovej skúsenosti (napr. Rusi v Tatrách, Česi v Liptove a v Tatrách), iné odhal'ujú menej očakávané situácie. Príkladom je analýza sezónnej návštevnosti užívatel'ov mobilnej siete zo Srbska, ktorá naznačuje iné ako turistické súvislosti.

Hoci je odhad presného počtu turistov prostredníctvom mobilnej lokalizácie pomerne problematický, identifikácia sezónnych vzorcov návštevnosti poskytuje vhodný analytický podklad pre manažment a cielený marketing turizmu na regionálnej úrovni. Súčasný trend vo výskume turizmu naznačuje zníženie všeobecného dôrazu na počet prenocovaní na národnej úrovni a zameriava sa na hodnotenie aktivít návštevníkov v regionálnej mierke s dôrazom na ich časovo-priestorové správanie. Lokalizačné údaje mobilnej siete ponúkajú možnosti práve takto orientovaného výskumu turizmu. Diferenciácia turistických destinácií z pohl'adu štruktúry návštevníkov nám umožňuje identifikovat' atraktivitu regiónov (lokalít, resp. konkrétnych turistických ciel’ov) pre návštevníkov z rôznych krajín. Táto skutočnost' má 
osobitný význam v malej krajine, akou je Slovensko, kde je väčšina ciel'ov l'ahko dosiahnutel'ných z jedného miesta a ubytovacia štatistika nemusí odrážat' skutočný pohyb návštevníkov $\mathrm{v}$ priestore.

Táto práca bola podporovaná Agentúrou na podporu výskumu a vývoja na základe Zmluvy č. APVV-16-0462 a APVV-16-0232 a grantom VEGA 2/0113/19. Osobitné pod'akovanie patri spoločnosti Market Locator SK za spoluprácu pri spracovani dát a technickej podpore.

\section{LITERATÚRA}

AHAS, R., AASA, A., MARK, U., PAE, T., KULL, A. (2007a). Seasonal tourism spaces in Estonia: case study with mobile positioning data. Tourism Management, 28, 898-910. DOI: 10.1016/j.tourman.2006.05.010.

AHAS, R., AASA, A., SILM, S., TIRU, M. (2007b). Mobile positioning data in tourism studies and monitoring: case study in Tartu, Estonia. In Sigala, M., Mich, L., Murphy, J., eds. Computer science: Information and communication technologies in tourism. Vienna (Springer), pp. 119-128.

AHAS, R., AASA, A., ROOSEA, A., MARK, Ü., SILMA, S. (2008). Evaluating passive mobile positioning data for tourism surveys: an Estonian case study. Tourism Management, 29, 469-486. DOI: 10.1016/j.tourman.2007.05.014.

AHAS, R., MARK, Ü. (2005). Location based services - new challenges for planning and public administration? Futures, 37, 547-561. DOI: 10.1016/j.futures.2004.10.012.

ARRIBAS-BEL, D. (2014). Accidental, open and everywhere: emerging data sources for the understanding of cities. Applied Geography, 49, 45-53. DOI: 10.1016/ j.apgeog.2013.09.012.

BENGTSSON, L., LU, X., THORSON, A., GARFIELD, R., VON SCHREEB, J. (2011). Improved response to disasters and outbreaks by tracking population movements with mobile phone network data: A post-earthquake geospatial study in Haiti. PLOS Medicine, 8, e1001083. DOI: 10.1371/journal.pmed.1001083.

BLONDEL, V. D., KRINGS, G., THOMAS, I. (2010). Regions and borders of mobile telephony in Belgium and in the Brussels metropolitan zone. Brussel Studies, 42, 1-12. DOI: $10.4000 /$ brussels.806.

BUHALIS, D. (2000). Marketing the competitive destination of the future. Tourism Management, 21, 97-116. DOI: 10.1016/S0261-5177(99)00095-3.

CALABRESE, F., RATTI, C. (2006). Real time Rome. Network and Communications Studies, 20, 247-258.

DUFKOVÁ, K., FICEK, M., KENCL, L., NOVÁK, J., KOUBA, J., GREGOR, I., DANIHELKA, J. (2008). Active GSM cell-id tracking: where did you disappear? In MELT 2008: Proceedings of the First ACM International Workshop on Mobile Entity Localization and Tracking in GPS-less Environments. San Francisco, pp. 7-12.

EUROPEAN COMMISSION (2018). The end of roaming charges one year later. Flash Eurobarometer 468, TNS Political \& Social, [Online]. Dostupné na: http://ec.europa.eu/ commfrontoffice/publicopinion/index.cfm/ResultDoc/download/DocumentKy/83165 [cit: 30-05-2019].

EUROSTAT (2017). Africa - EU: key statistical indicators, [Online]. Dostupné na: https:// ec.europa.eu/eurostat/statistics-explained/pdfscache/3776.pdf [cit. 26-06-2019].

FRAMKE, W. (2002). The destination as a concept: a discussion of the business related perspective versus the socio-cultural approach in tourism theory. Scandinavian Journal of Hospitality and Tourism, 2, 92-108. DOI: 10.1080/15022250216287.

FRATTASI, S., DELLA ROSA, F. (2017). Mobile positioning and tracking: from conventional to cooperative techniques. Chichester (Wiley).

HÄGERSTRAND, T. (1970). What about people in regional science? Papers of the Regional Science, 24, 7-21. DOI: 10.1111/j.1435-5597.1970.tb01464.x. 
IRA, V. (2001). Geografia času: prístup, základné koncepty a aplikácie. Geografický časopis, 53, 231-246.

KREMSKÝ, P. (2015). Talenty pre Slovensko. Podnikatel’ská aliancia Slovenska, [Online]. Dostupné na https://www.alianciapas.sk/wp-content/uploads/2015/12/Talenty-preSlovensko.pdf [cit:29.5.2019].

LAMBIOTTE, R., BLONDEL, V. D., DEKERChOVE, C., HUENS, E., PRIEUR, C., SMOREDA, Z. (2008). Geographical dispersal of mobile communication networks. Physica A: Statistical Mechanics and its Applications, 387, 5317-5325. DOI: 10.1016/ j.physa.2008.05.014.

LENNTORP, B. (1976). Paths in time-space environments: a time-geographic study of movement possibilities of individuals. Lund (Royal University of Lund).

LI, J., XU, L., TANG, L., WANG, S., LI, L. (2018). Big data in tourism research: a literature review. Tourism Management, 68, 301-323. DOI: 10.1016/j.tourman.2018.03.009.

MAMEI, M., COLONNA, M. (2018). Analysis of tourist classification from cellular network data. Journal of Location Based Services, 12, 19-39. DOI: 10.1080/ 17489725.2018.1463466.

MEDINA, L., SCHNEIDER, F. (2018). Shadow economies around the world: what did we learn over the last 20 years? IMF Working Papers WP 18/17, [Online]. Dostupné na: https://www.imf.org/ /media/Files/Publications/WP/2018/wp1817.ashx [cit. 26-062019].

NILBE, K., AHAS, R., SILM, S. (2014). Evaluating the travel distances of events visitors and regular visitors using mobile positioning data: the case of Estonia. Journal of Urban Technology, 21, 91-107. DOI: 0.1080/10630732.2014.888218.

NOVÁK, J. (2010). Lokalizační data mobilních telefonü: možnosti využití v geografickém výzkumu. Dizertačná práca, Praha (Univerzita Karlova v Prahe).

NOVÁK, J., AHAS, R., AASA, A., SILM, S. (2013). Application of mobile phone location data in mapping of commuting patterns and functional regionalization: a pilot study of Estonia. Journal of Maps, 9, 10-15. DOI: 10.1080/17445647.2012.762331.

PHITHAKKITNUKOON, S., HORANONT, T., WITAYANGKURN, A., SIRI, R., SEKIMOTO, Y., SHIBASAKI, R. (2015). Understanding tourist behaviour using largescale mobile sensing approach: a case study of mobile phone users in Japan. Pervasive and Mobile Computing, 18, 18-39. DOI: 10.1016/j.pmcj.2014.07.003.

RATTI, C., FRENCHMAN, D., PULSELLI, R., WILLIAMS, S. (2006). Mobile landscape: using location data from cell phones for urban analysis. Environment and Planning $B$ : Planning and Design, 33, 727-748. DOI: 10.1068/b32047.

RAUN, J., AHAS, R., TIRU, M. (2016). Measuring tourism destinations using mobile tracking data. Tourism Management, 57, 202-212. DOI: 10.1016/j.tourman. 2016.06.006.

SONG, C., QU, Z., BLUMM, N., BARABÁSI, A.-L. (2010). Limits of predictability in human mobility. Science, 327, 1018-1021. DOI: 10.1126/science.1177170.

ŠÚ SR (2017). Návštevníci v ubytovacích zariadeniach cestovného ruchu. Bratislava (Štatistický úrad SR).

ŠVEDA, M., KRIŽAN, F., BARLÍK, P. (2017). Využitie údajov mobilných sietí a služieb založených na lokalizácii v geografii maloobchodu a služieb. In Križan, F., Bilková, K., Barlík, P., eds. Maloobchod a špecifiká časovo-priestorového správania spotrebitelov. Bratislava (Univerzita Komenského v Bratislave), pp. 241-258.

STEENBRUGGEN, J., TRANOS, E., NIJKAMP, P. (2015). Data from mobile phone operators: a tool for smarter cities? Telecommunications Policy, 39, 335-346. DOI: 10.1016/ j.telpol.2014.04.001.

TOOLE, J., COLAK, S., STURT, B., ALEXANDER, L., EVSUKOFF, A., GONZÁLEZ, M. (2015). The path most traveled: travel demand estimation using big data resources. Transportation Research Part C, 58, 162-177. DOI: 10.1016/j.trc.2015.04.022.

WANG, Z., HE, S. Y., LEUNG, Y. (2018). Applying mobile phone data to travel behaviour research: a literature review. Travel Behaviour and Society, 11, 141-155. DOI: 10.1016/ j.tbs.2017.02.005. 
WESOLOWSKI, A., EAGLE, N., TATEM, A. J., SMITH, D. L., NOOR, A. M., SNOW, R. W., BUCKEE, C. O. (2012). Quantifying the impact of human mobility on malaria. Science, 338, 267-270. DOI: 10.1126/science.1223467.

Dátové zdroje:

O2 Slovakia (2017). Pasívne lokalizačné údaje o pohybe zahraničných SIM-kariet na Slovensku v roku 2016. Spracovanie údajov: Market Locator SK, Bratislava.

Slovak Telekom (2017). Pasívne lokalizačné údaje o pohybe zahraničných SIM-kariet na Slovensku v roku 2016. Spracovanie údajov: Market Locator SK, Bratislava.

Orange Slovensko (2017). Pasívne lokalizačné údaje o pohybe zahraničných SIM-kariet na Slovensku v roku 2016. Spracovanie údajov: Market Locator SK, Bratislava.

$$
\text { Martin } \check{S} v \text { eda, František Križan, Peter Barlik }
$$

\section{UTILIZING MOBILE POSITIONING DATA IN TOURISM: WHO ARE THE FOREIGN VISITORS IN SLOVAKIA? WHEN DO THEY COME AND WHERE THEY STAY?}

A new possibility for measuring visitors flows in destinations quantitatively is via the use of mobile positioning data. In the study, we analysed empirically the geographical, temporal and compositional dimensions, by using data on the visit of foreign visitors to Slovakia gathered through access to the anonymised passive mobile positioning data of three major national mobile network operators.

The paper aims to evaluate the temporal and spatial aspects of foreign visitors in Slovakia using mobile positioning data and find the answers for the following research questions:

- Does the localization via mobile network identify time (seasonal) and spatial (regional) patterns of particular nationalities?

- What is the space-time image of foreign visitors in Slovakia provided by mobile positioning data?

- How do the obtained mobile positioning data correspond with the official statistics (nights spent at tourist accommodation establishments) and how to interpret differences?

The passive mobile positioning data used in this study is based on the call detail records (CDR), which are produced by a cellphone exchange or other telecommunication equipment that documents the details of a phone call or other telecommunication transactions that pass through that facility or device. The record contains spatial (network cell) and temporal information and the country of the users registration.

We used the roaming data of foreign mobile phones in Slovakia. The first dataset consists of all foreign visitors, who made at least one telecommunication activity during the year 2016. The database consists of a total of 14365194 unique phone IDs (visitors). The second dataset is a selection of visitors who spent 2-14 days during the studied period. Observations longer than 14 days are excluded as staying in one country for more than 14 days may also mean that Slovakia functions as a secondary home, which is not considered as falling under classical tourism. The database consists of a total of 6027633 unique phone IDs, and we have identified these visitors as "tourists". The study was conducted at a district level, to compare the spatiotemporal characteristics of destinations with the conventional data of nights spent at tourist accommodation establishments.

The most visited district in Slovakia is Bratislava, which dominates the tourism market significantly. The capital city functions as the sole destination for $19 \%$ of foreign visitors. The second largest city - Košice - recorded only 3\% of foreign visitors. The other most visited districts are concentrated along the main transportation corridor, which connects the capital city with the northern and eastern parts of Slovakia, and districts which perform 
as a gateway for foreign visitors. This geographical distribution of phone activity events illustrates the dependency on transit traffic. Extracting the group of "tourist" reduced the initial dataset by half. We modeled the seasonal pattern of visitor flows to destinations and on the example of selected districts, we demonstrate the seasonal pattern of tourists from selected countries.

The majority of tourists is made in a similar proportion by Czech $(28 \%)$, Polish $(22 \%)$, and Hungarian $(9 \%)$ users of a mobile network. The relative importance of German $(7 \%)$ and Austrian (6\%) visitors to Slovakia is also notable. Analysis of the nationalities revealed temporal preferences. Most visitors are summer oriented, more than $35 \%$ of total visits are made during the summer months.

In terms of spatial distribution, the highest number of localization records was recorded mainly by border districts. This fact reflects localisation data distortion caused by mobile network overlaps into neighboring countries (hand-over noise). However, mobile positioning data can be considered useful for analyzing seasonal aspects of tourism in Slovakia and the destination preferences of foreign visitors. Some findings correspond to general experience (e.g. Czech and Russian tourists in the High Tatras Region), others reveal less expected situations. One peculiarity can be seen in the case of Serbian visits to western parts of Slovakia, where the equally distributed proportion of visits can be explained by the large numbers of Serbian workers coming to Slovakia for long-term employment contracts.

The comparison between the visitor's origin with the official statistics based on nights spent at tourist accommodation establishments showed a relatively strong correlation. However, this is the case only when considering the total number of unique visitors throughout Slovakia. However, at a district level, the correlation between the number of visitors in accommodation and the number of localisation records of tourists falling apart. This is mainly due to the border districts and districts situated on the main transit corridors such as Bratislava V, Svidník, Senica and Čadca, where the number of localisation records significantly exceeds the accommodation statistics. Differences are mainly due to the limited ability to filter real tourism participants from transit visitors (transit traffic) and cross-border connections from neighboring countries.

Developing destination monitoring tools based on positioning data is important above all for solving the management and marketing of tourism. The results proved that mobile positioning data has valuable applications for tourism studies, but there is still the question of extracting more precise information from the quantitative database with limited features. Yet, there is a need to obtain additional information, as we do not know any other information about the visitors besides their country of origin. However, further developments in space-time tracking would probably generate more detailed data. 
